\title{
Metallomics
}

CrossMark $\leftarrow$ click for updates

Cite this: Metallomics, 2017, 9, 278

Received 21st December 2016, Accepted 24th January 2017

DOI: $10.1039 / c 6 m t 00299 d$

rsc.li/metallomics

\section{Copper binding and redox chemistry of the $A \beta 16$ peptide and its variants: insights into determinants of copper-dependent reactivity $\dagger$}

\author{
Nineveh Yako, Tessa R. Young, Jade M. Cottam Jones, Craig A. Hutton, \\ Anthony G. Wedd and Zhiguang Xiao*
}

\begin{abstract}
The metal-binding sites of $A \beta$ peptides are dictated primarily by the coordination preferences of the metal ion. Consequently, $\mathrm{Cu}(\mathrm{I})$ is typically bound with two His ligands in a linear mode while $\mathrm{Cu}\left({ }^{\prime}\right)$ forms a pseudo-square planar stereochemistry with the $\mathrm{N}$-terminal amine nitrogen acting as an anchoring ligand. Several distinct combinations of other groups can act as co-ligands for $\mathrm{Cu}(I)$. A population of multiple binding modes is possible with the equilibrium position shifting sensitively with solution $\mathrm{pH}$ and the nature of the residues in the $\mathrm{N}$-terminal region. This work examined the $\mathrm{Cu}(\Perp)$ chemistry of the $\mathrm{A} \beta 16$ peptide and several variants that targeted these binding modes. The results are consistent with: (i) at $\mathrm{pH}<7.8$, the square planar site in $\mathrm{Cu}^{\prime \prime}-\mathrm{A} \beta 16$ consists primarily of a bidentate ligand provided by the carboxylate sidechain of Asp1 and the $\mathrm{N}$-terminal amine supported by the imidazole sidechains of two His residues (designated here as component IA); it is in equilibrium with a less stable component IB in which the carboxylate ligand is substituted by the Asp1-Ala2 carbonyl oxygen. (ii) Both IA and IB convert to a common component II (apparent transition $\mathrm{p} K_{\mathrm{a}} \sim 7.8$ for IA and $\sim 6.5$ for IB, respectively) featuring a tridentate ligand consisting of the N-terminal amine, the Asp1-Ala2 amide and the Ala2-Pro3 carbonyl; this stereochemistry is stabilized by two five-membered chelate rings. (iii) Component IA is stabilized for variant $A \beta 16-D 1 H$, components I (both IA and IB) are imposed on $A \beta 16-A 2 P$ while the less stable IB is enforced on $\mathrm{A} \beta 16-\mathrm{D} 1 \mathrm{~A}$ (which is converted to component II at $\mathrm{pH} \sim 6.5$ ); (iv) components IA and IB share two His ligands with $\mathrm{Cu}(\mathrm{I})$ and are more reactive in redox catalysis than component II that features a highly covalent and less reactive amide $\mathrm{N}^{-}$ligand. The redox activity of IA is further enhanced for peptides with a His1 $\mathrm{N}$-terminus that may act as a ligand for either $\mathrm{Cu}(\mathrm{I})$ or $\mathrm{Cu}(\mathrm{I})$ with lower re-organization energy required for redox-shuttling. This study provided insights into the determinants that regulate the reactivity of $\mathrm{Cu}-\mathrm{A} \beta$ complexes.
\end{abstract}

Significance to metallomics

Copper binding to $\mathrm{A} \beta$ peptides has been subjected to recent intensive studies due to its possible relevance to the aetiology of Alzheimer's disease. Multiple metal binding ligands are present in the soluble and unstructured $\mathrm{N}$-terminal section of $\mathrm{A} \beta(x-16)$, where $x>1$ indicates truncation. The nature of the copper binding modes is dictated by the coordination preference of the copper oxidation state and by the medium $\mathrm{pH}$, as is the reactivity of the $\mathrm{Cu}-\mathrm{A} \beta$ complexes. This study clarifies current controversy regarding several important $\mathrm{Cu(II)}$ binding modes and provides an improved understanding of the complex copper chemistry of $\mathrm{A} \beta$ peptides.

School of Chemistry and The Bio21 Molecular Science and Biotechnology Institute, The University of Melbourne, Parkville, Victoria 3010, Australia.

E-mail: z.xiao@florey.edu.au; Fax: +61 39347 5180; Tel: +61 390356072

$\dagger$ Electronic supplementary information (ESI) available: Conditional $\mathrm{Cu}(\mathrm{II})$ dissociation constants (Table S1), pH-dependent EPR spectra (Fig. S1-S7). See DOI: $10.1039 / \mathrm{c} 6 \mathrm{mt} 00299 \mathrm{~d}$

\# Present address: The Florey Institute of Neuroscience and Mental Health, The University of Melbourne, Parkville, Vic 3010, Australia.

\section{Introduction}

Disruption of metal homeostasis has been linked to Alzheimer's disease and undesirable interactions between $\mathrm{A} \beta$ peptides and copper ions may play roles in the promotion of toxic $A \beta$ aggregation and/or in the catalytic production of reactive oxygen species (ROS). ${ }^{1,2}$ Monomeric $A \beta$ peptides are flexible and unstructured and the copper binding sites and binding modes 
(a) Cu' forms

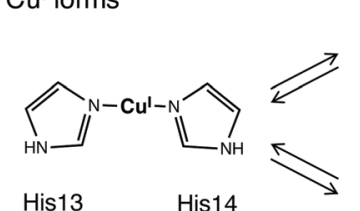

Cull forms at low $\mathrm{pH}$

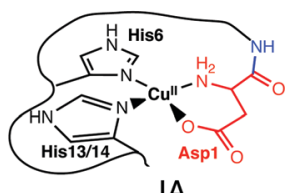

IA

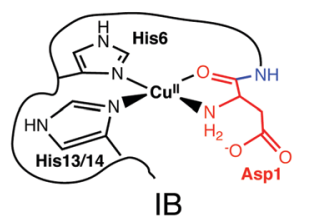
carboxylates or water. and redox catalysis., ${ }^{5,6}$
Fig. 1 Proposed models of coordination of the $A \beta$ peptide to $\mathrm{Cu}(\mathrm{I})(\mathrm{a})$ and $\mathrm{CU}(\mathrm{II})(\mathrm{b})$. Note: only the equatorial ligands are indicated for the $\mathrm{Cu}(\mathrm{II})$ sites, and possible weakly binding axial ligands may include various side-chain

change dynamically with the oxidation state and $\mathrm{pH},{ }^{3,4}$ as does the reactivity of the metal centres towards ligand substitution

Previous studies have demonstrated that $\mathrm{A} \beta$ peptides bind $\mathrm{Cu}(\mathrm{I})$ in dynamic linear two-coordinate modes utilizing the three different combinations of the available His-6, -13 and -14 sidechains (Fig. 1a). ${ }^{7,8}$ In contrast, they typically bind $\mathrm{Cu}(\mathrm{II})$ in a square planar-based stereochemistry. The N-terminal amine nitrogen acts as a primary anchoring ligand. Depending on the conditions, several distinct combinations of other groups can act as co-ligands. The speciation depends sensitively on the medium $\mathrm{pH}$ and on the nature of the available co-ligands including the His residues, the sidechain of Asp1 and the carbonyl oxygen or deprotonated amide nitrogen of the Asp1-Ala2 peptide link (Fig. 1b). ${ }^{3,4}$ Note the presence of stabilizing six- or five-membered chelate rings in each $\mathrm{Cu}$ (II) complex.

The three distinct complexes in Fig. 1b are designated as components IA, IB and II in this work. Notably, they each can incorporate different combinations of His ligands as they appear to be conformationally available. Structure IA has frequently been proposed as a coordination mode at lower $\mathrm{pH} .{ }^{9-11}$ However, recently IB has been preferred, based mainly on EPR studies., ${ }^{4,12,13}$

A transition from components IA/B to component II requires deprotonation of the peptide amide of Ala2 and is promoted by elevated $\mathrm{pH}$. Any modification or truncation to the N-terminal residues, as occurs in native $\mathrm{A} \beta$ peptides, ${ }^{14,15}$ can alter the $\mathrm{Cu}$ (II) binding modes dramatically. For example, both the substitution of Asp1 with Asn and deletion of Asp1 to impose Ala2 as the $\mathrm{N}$-terminal residue in the $\mathrm{A} \beta 16$ peptide lead to a decrease of over

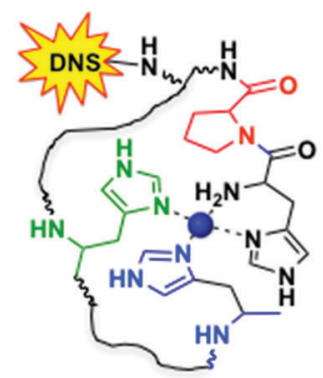

(a) DP3 probe (b) DP4 probe

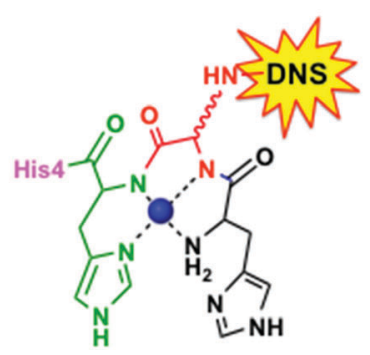

Fig. 2 Proposed equatorial Cu(॥) ligands in DP3 and DP4 (see Table 1 for sequences). ${ }^{21}$ Possible axial coordination ligand(s) include carboxylate(s) from Asp4 and/or Asp6 in DP3 and imidazole nitrogen ligand(s) from His1 and/or His4 in DP4. DNS = dansyl fluorophore.

one $\mathrm{pH}$ unit in the $\mathrm{p} K_{\mathrm{a}}$ of transition I $\rightarrow$ II. ${ }^{16-19}$ Deletion of the first three residues, as detected in native $A \beta$ peptides in high proportion, ${ }^{14,15}$ generates a classic $\mathrm{N}$-terminal $\mathrm{H}_{2} \mathrm{~N}-\mathrm{X}$-X-His3 motif known as the ATCUN (amino terminal copper and nickel) binding motif: the $\mathrm{Cu}(\mathrm{II})$ centre is stabilized by three chelate rings in a tetradentate ligand (Fig. 2 b). ${ }^{20-23}$

The different binding modes sensitively affect the reactivity of $\mathrm{Cu}-\mathrm{A} \beta$ complexes towards ligand substitution and redox catalysis, especially for $\mathrm{Cu}(\mathrm{II}){ }^{5,6,8,16,17}$ This study undertook a range of chemical and spectroscopic studies of the copper chemistry of the $A \beta 16$ peptide to provide improved insight into the relationship between binding mode and reactivity. In particular, several variants that targeted the $\mathrm{Cu}$ (II) binding site specifically were examined. The work was facilitated by the recent development of a set of peptide-based fluorescent dansyl probes DP1-4 that are able to quantify $\mathrm{Cu}$ (II) binding stoichiometries and affinities from micromolar to femtomolar concentrations on a unified scale. ${ }^{8,21}$ The combined data demonstrated that (i) the $\mathrm{A} \beta 16$ peptide binds $\mathrm{Cu}(\mathrm{II})$ dominantly as component IA in equilibrium with less stable IB at low $\mathrm{pH}$, while at higher $\mathrm{pH}$, component II predominates (Fig. 1b); (ii) component I is more reactive than component II in redox catalysis.

\section{Experimental section}

\section{Materials and general procedure}

Materials purchased from Sigma included the ligands Ferene S (Fs), Ferrozine (Fz) and bicinchoninic anion (Bca) (as their sodium salts $\mathrm{Na}_{2} \mathrm{Fs}, \mathrm{NaHFz}$ and $\mathrm{Na}_{2} \mathrm{Bca}$ ), and the reductants $\mathrm{NH}_{2} \mathrm{OH}$ (as its $\mathrm{H}_{2} \mathrm{SO}_{4}$ salt) and ascorbic acid (Asc). They were all used as received. A standard $\mathrm{Cu}$ (II) solution was prepared by dissolving $\mathrm{CuSO}_{4}$ in Milli-Q water and the concentration calibrated via reaction with excess of the $\mathrm{Cu}(\mathrm{I})$-binding ligand $\mathrm{Bca}$ in Mops buffer containing reductant $\mathrm{NH}_{2} \mathrm{OH}$. Under such conditions, all copper ions are converted quantitatively to the well-defined chromophoric complex anion $\left[\mathrm{Cu}^{\mathrm{I}}(\mathrm{Bca})_{2}\right]^{3-}$ with characteristic absorbance at $562 \mathrm{~nm}\left(\varepsilon=7900 \mathrm{M}^{-1} \mathrm{~cm}^{-1}\right) .{ }^{24}$ The peptides and probes listed in Table 1 were purchased from GL Biochem (Shanghai) except for A $\beta 16-\mathrm{A} 2 \mathrm{P}$ and $\mathrm{A} \beta 16-\mathrm{D} 1 \mathrm{H} / \mathrm{H} 14 \mathrm{~A}$ which were synthesized on site by standard solid phase peptide techniques as 
Table 1 Sequences of $A \beta 16$ peptides and probes ${ }^{a}$

\begin{tabular}{llrr}
\hline & & \multicolumn{2}{c}{ Molar mass (Da) } \\
\cline { 3 - 4 } Peptide or probe & Sequence & Calcd & Found \\
\hline A $\beta 16$ & DAEFRHDSGYEVHHQK & 1955.0 & 1954.5 \\
Ac-A $\beta 16$ & Ac-DAEFRHDSGYEVHHQK & 1997.0 & 1997.5 \\
D1A & AAEFRHDSGYEVHHQK & 1911.0 & 1910.7 \\
D1E & EAEFRHDSGYEVHHQK & 1969.0 & 1970.4 \\
D1N & NAEFRHDSGYEVHHQK & 1954.0 & 1954.9 \\
D1H & HAEFRHDSGYEVHHQK & 1977.0 & 1978.0 \\
D1H/H14A & HAEFRHDSGYEVHAQK & 1911.0 & 1911.4 \\
A2P & DPEFRHDSGYEVHHQK & 1981.0 & 1981.5 \\
DP2 & DAE(K ${ }^{\text {DNS }}$ )RHDH & 1240.3 & 1240.9 \\
DP3 & HP(K ${ }^{\text {DNS }}$ )DHDH & 1118.2 & 1118.0 \\
DP4 & H(K ${ }^{\text {DNS }}$ )HH & 790.8 & 790.4 \\
$a$ & & & \\
The residues changed are underlined in bold. & & \\
\hline
\end{tabular}

detailed previously. ${ }^{25}$ The identity of each peptide was verified by electrospray ionization mass spectrometry (ESI-MS; Table 1) while the purity was confirmed to be $>98 \%$ by HPLC. Peptide concentrations were estimated from absorbance maxima at $\sim 276 \mathrm{~nm}$ using $\varepsilon_{\max }=1410 \mathrm{M}^{-1} \mathrm{~cm}^{-1}$ for $\mathrm{A} \beta 16$ peptides containing a single tyrosine residue. The concentration of dansyl peptide probes DP2-4 was estimated by absorbance maxima at $\sim 326 \mathrm{~nm}$ using the reported $\varepsilon_{\max }=4500 \mathrm{M}^{-1} \mathrm{~cm}^{-1}$ for each probe. ${ }^{21}$ The concentrations obtained matched those estimated from fluorescence titrations with the copper standard assuming the formation of a $1: 1$ complex.

All ligand stock solutions, reaction buffers, reductant solutions and protein solutions were prepared in rigorously deoxygenated Milli-Q water and stored in an anaerobic glove-box $\left(<1 \mathrm{ppm} \mathrm{O}_{2}\right)$. The working solution of ligand Fs was prepared freshly from aliquots of frozen stock solution stored in a freezer at temperature $-80{ }^{\circ} \mathrm{C}^{26}$ All reactions involving $\mathrm{Cu}(\mathrm{I})$ were performed anaerobically in the glove-box and transported outside in a capped cuvette for spectroscopic characterization.

\section{Spectroscopic methods}

UV-visible spectra were recorded on a Varian Cary 300 spectrophotometer in the dual beam mode with quartz cuvettes. All metal titrations were performed in appropriate buffers and corrected for baseline and dilution. Fluorescence emission spectra were recorded on a Varian Cary Eclipse spectrophotometer with a band pass of $20 \mathrm{~nm}$ for both excitation and emission. The excitation wavelength for the dansyl peptide (DP) probes was $330 \mathrm{~nm}$ and the emission spectra were recorded between 450 and $750 \mathrm{~nm}$ at a scan rate of $600 \mathrm{~nm} \min ^{-1}$. Electron paramagnetic resonance (EPR) spectra were recorded on a Bruker Elexsys E 500 EPR spectrometer under the following instrument conditions: microwave frequency $\nu=9.456-9.495 \mathrm{GHz}$ but conversion to a single frequency of $9.475 \mathrm{GHz}$ for reporting via relationship $g=714.4775 \nu / F$, where $F$ is the magnetic field in the Gauss unit, the microwave power is $\sim 1 \mathrm{~mW}$, the modulation amplitude is $4 \mathrm{G}$, the modulation frequency is $100 \mathrm{kHz}$, the sweep time is $40 \mathrm{~s}$, the time constant is $20 \mathrm{~ms}$, and the average number of scans is 10 . All sample solutions (total $0.2 \mathrm{~mL}$ ) were prepared in $50 \mathrm{mM}$ buffer (Mes at $\mathrm{pH}$ 5.9-6.5; Mops at $\mathrm{pH}$ 6.6-8.0 or Ches at $\mathrm{pH}>8$ ) containing $[\mathrm{Cu}(\mathrm{II})]_{\mathrm{tot}}=0.45 \mathrm{mM}$, [peptide or probe] $]_{\text {tot }}=0.5 \mathrm{mM}$ and $5 \%$ glycerol. The solution $\mathrm{pH}$ of each sample was re-checked after recording each spectrum. The samples were snap-frozen in liquid nitrogen and the spectra recorded at $77 \mathrm{~K}$ in a liquid-nitrogen finger Dewar. The EPR parameters ( $g$ values and $A$ values) were extracted directly from the recorded spectra without simulation.

\section{Quantification of $\mathrm{Cu}$ (II) binding}

$\mathrm{Cu}(\mathrm{II})$ binding to $\mathrm{A} \beta$ peptides was quantified with a series of DP probes as reported recently. ${ }^{21}$ These probes feature a dansyl group and emit intense fluorescence at $\lambda_{\max } \sim 550 \mathrm{~nm}$ upon excitation at $\sim 330 \mathrm{~nm}$. They bind one equiv. of $\mathrm{Cu}$ (II) with varying affinities and $\mathrm{Cu}$ (II) binding to the probes is detected sensitively via proportional fluorescence quenching. The quantification is based on the following relationships:

$$
\begin{gathered}
\mathrm{Cu}^{\mathrm{II} D P}+\mathrm{A} \beta \rightleftharpoons \mathrm{Cu}^{\mathrm{II}} \mathrm{A} \beta+\mathrm{DP} \\
K_{\mathrm{ex}}=\frac{\left[\mathrm{Cu}^{\mathrm{II}} \mathrm{A} \beta\right][\mathrm{DP}]}{\left[\mathrm{Cu}^{\mathrm{II}} \mathrm{DP}\right][\mathrm{A} \beta]}=\frac{K_{\mathrm{D}}\left(\mathrm{Cu}^{\mathrm{II}} \mathrm{DP}\right)}{K_{\mathrm{D}}\left(\mathrm{Cu}^{\mathrm{II}} \mathrm{A} \beta\right)} \\
\frac{[\mathrm{A} \beta]_{\text {tot }}}{[\mathrm{DP}]_{\text {tot }}}=\frac{[\mathrm{Cu}]_{\text {tot }}-\left[\mathrm{Cu}^{\mathrm{II}} \mathrm{DP}\right]}{[\mathrm{DP}]_{\text {tot }}} \\
+\frac{K_{\mathrm{D}}\left(\mathrm{Cu}^{\mathrm{II}} \mathrm{A} \beta\right)}{K_{\mathrm{D}}\left(\mathrm{Cu}^{\mathrm{II}} \mathrm{DP}\right)}\left(\frac{[\mathrm{Cu}]_{\text {tot }}}{\left[\mathrm{Cu}{ }^{\mathrm{II}} \mathrm{DP}\right]}-1\right)\left(1-\frac{\left[\mathrm{Cu}^{\mathrm{II}} \mathrm{DP}\right]}{[\mathrm{DP}]_{\text {tot }}}\right) \\
\frac{\left[\mathrm{Cu}{ }^{\mathrm{II}} \mathrm{DP}\right]}{[\mathrm{DP}]_{\text {tot }}}=\frac{F_{0}-F}{F_{0}-F_{1}}=\frac{\Delta F}{\Delta F_{1}}
\end{gathered}
$$

where $K_{\mathrm{D}}\left(\mathrm{Cu}{ }^{\mathrm{II}} \mathrm{A} \beta\right)$ and $K_{\mathrm{D}}\left(\mathrm{Cu}^{\mathrm{II}} \mathrm{DP}\right)$ are the respective dissociation constants under the same conditions. Eqn (3) is derived from eqn (2) with incorporation of mass balance relationships for an effective competition described by eqn (1) and is a convenient format for curve-fitting of the experimental data to derive $K_{\mathrm{D}}\left(\mathrm{Cu}{ }^{\mathrm{II}} \mathrm{A} \beta\right)$ with known $K_{\mathrm{D}}\left(\mathrm{Cu}^{\mathrm{II}} \mathrm{DP}\right)$. Under the conditions of the fluorescent emission of the dansyl probes $\left(\lambda_{\mathrm{ex}}=330 \mathrm{~nm} ; \lambda_{\mathrm{em}}=550 \mathrm{~nm}\right)$, the $\mathrm{A} \beta$ peptides are fluorescence-silent. Consequently, the $\mathrm{Cu}$ (II) speciation in eqn (1)-(3) may be analysed conveniently and reliably by monitoring the response of the probe to binding of $\mathrm{Cu}$ (II) via eqn (4), where $F_{0}, F$ and $F_{1}$ are the fluorescence intensity of the DP probe upon binding $0,<1.0$ and 1.0 equiv. of $\mathrm{Cu}(\mathrm{II})$, respectively. The experiments were performed via reported protocols. ${ }^{21}$

The $K_{\mathrm{D}}$ values for each peptide were determined similarly at a range of $\mathrm{pH}$ values. The $\mathrm{pH}$-dependent affinities of the $\mathrm{Cu}$ (II) probes DP2-4 have been reported recently. ${ }^{21}$ If the $\mathrm{Cu}(\mathrm{II})$ binding site remains unchanged within a $\mathrm{pH}$ range and the ligand compositions are known, then the conditional $K_{\mathrm{D}}$ within that $\mathrm{pH}$ range may be correlated with the absolute dissociation constant $\left(K_{\mathrm{D}}^{\mathrm{abs}}\right)$ and the proton ionization constants $\left(K_{\mathrm{an}}\right)$ of each ligand function of the site according to eqn (5):

$$
K_{\mathrm{D}}=K_{\mathrm{D}}^{\mathrm{abs}}\left(1+\sum_{i=1}^{n} 10\left(\sum_{i=1}^{n} \mathrm{p} K_{\mathrm{a} i}-i \mathrm{pH}\right)\right)
$$

The experiments were conducted in buffers (50 mM) Mes (pH 6.0-6.6), Mops (pH 7.0-7.4), Hepes (pH 7.8-8.2) and Ches 
(pH 8.5-9.2). On the other hand, the relationship between the determined $K_{\mathrm{D}}$ and $\mathrm{pH}$ may also be employed to model the most likely binding site using eqn (5) to derive $K_{\mathrm{D}}^{\mathrm{abs}}$ for the $\mathrm{Cu}$ (II) complex and $K_{\mathrm{an}}$ for the possible binding ligands.

\section{Quantification of Cu(I) binding}

Competition for $\mathrm{Cu}(\mathrm{I})$ with a suitable probe ligand $\mathrm{L}(\mathrm{L}=$ Fs or $\mathrm{Fz}$ ) was set up according to eqn (6) and (7): ${ }^{26}$

$$
\begin{aligned}
& {\left[\mathrm{Cu}^{\mathrm{I}} \mathrm{L}_{2}\right]^{3-}+\mathrm{A} \beta \rightleftharpoons \mathrm{Cu}^{\mathrm{I}} \mathrm{A} \beta+2 \mathrm{~L}^{2-}} \\
& \frac{[\mathrm{A} \beta]_{\text {tot }}}{\left[\mathrm{Cu}^{\mathrm{I}}\right]_{\mathrm{tot}}}=1-\frac{\left[\mathrm{Cu}^{\mathrm{I}} \mathrm{L}_{2}\right]}{\left[\mathrm{Cu}^{\mathrm{I}}\right]_{\mathrm{tot}}} \\
& +K_{\mathrm{D}} \beta_{2}\left(\frac{[\mathrm{L}]_{\text {tot }}}{\left[\mathrm{Cu}^{\mathrm{I}} \mathrm{L}_{2}\right]}-2\right)^{2}\left[\mathrm{Cu}^{\mathrm{I}} \mathrm{L}_{2}\right]\left(1-\frac{\left[\mathrm{Cu}^{\mathrm{I}} \mathrm{L}_{2}\right]}{\left[\mathrm{Cu}^{\mathrm{I}}\right]_{\text {tot }}}\right)
\end{aligned}
$$

where $\beta_{2}$ is the known formation constant for the chromophoric probe complex $\left[\mathrm{Cu}^{\mathrm{I}} \mathrm{L}_{2}\right]^{3-}$ whose equilibrium concentration may be determined directly from the specific solution absorbance. The dissociation constant $K_{\mathrm{D}}$ for the $\mathrm{Cu}^{\mathrm{I}}-\mathrm{P}$ complex was determined by curve-fitting of the experimental data to eqn (7). Probe ligands Fs and $\mathrm{Fz}$ were employed and they bind $\mathrm{Cu}(\mathrm{I})$ with different affinities $\left(\log \beta_{2}=13.7\right.$ for $\mathrm{L}=\mathrm{Fs}$ and 15.1 for $\left.\mathrm{L}=\mathrm{Fz}\right) .{ }^{26}$ The experiments were performed via reported protocols. ${ }^{26}$

\section{Catalytic aerobic oxidation of ascorbate}

Experiments were conducted in air-saturated Mops buffers (50 mM; pH 6.6 and 7.4) and Ches buffer (50 mM, pH 8.7). To minimize the catalytic effect from unbound copper, a stock solution of each $\mathrm{Cu}$-peptide complex was prepared with onefold excess of the corresponding apo-peptide and the total copper content quantified accurately with the $\mathrm{Cu}(\mathrm{I})$ probe $\mathrm{Bcs}$ as a stable chromophoric complex $\left[\mathrm{Cu}^{\mathrm{I}}(\mathrm{Bcs})_{2}\right]^{3-}\left(\log \beta_{2}=19.9\right.$; $\left.\varepsilon_{483}=13000 \mathrm{M}^{-1} \mathrm{~cm}^{-1}\right) .{ }^{27}$ The reactions were conducted using a quartz mixing cuvette where one half-cell was loaded with Asc $(\sim 100 \mu \mathrm{M})$ and the other half-cell with the $\mathrm{Cu}^{\mathrm{II}}-\mathrm{A} \beta$ complex (varying in concentration between 2 and $40 \mu \mathrm{M}$, dependent on the catalytic activity). After recording the background reaction (if any), the catalytic reaction was started by quick mixing (note: the concentration of each component in the half-cells becomes half after the mixing) and followed in real time by the change in absorbance $\mathrm{A}_{265}$ of the reduced Asc. The oxidation rate was expressed as $\mu \mathrm{M} \min ^{-1}$ and calculated using the extinction coefficient $\varepsilon_{265}=14500 \mathrm{M}^{-1} \mathrm{~cm}^{-1}$ for Asc. ${ }^{28}$ The catalytic activity of each $\mathrm{Cu}-\mathrm{A} \beta$ complex was expressed as molar turn-over number per $\min (\mathrm{MTN} / \mathrm{min}$ ) and was obtained from the slope of a linear plot of the Asc oxidation rate $\left(\mu \mathrm{M} \mathrm{min}{ }^{-1}\right)$ versus the concentration $(\mu \mathrm{M})$ of each $\mathrm{Cu}-\mathrm{A} \beta$ complex. The background oxidation rate without added $\mathrm{Cu}$ has been removed from the determined oxidation rate.

\section{Formal reduction potential}

The formal reduction potential of the copper centres in each $\mathrm{Cu}-\mathrm{Ab} 16$ complex was estimated from the relative affinities of the peptides for $\mathrm{Cu}(\mathrm{I})$ and $\mathrm{Cu}(\mathrm{II})$ under the same conditions via the Nernst relationship of eqn (8):

$$
E^{0^{\prime}}(\mathrm{mV})=E^{0}+59 \log \left(\frac{K_{\mathrm{D}}\left(\mathrm{Cu}^{\mathrm{II}}\right)}{K_{\mathrm{D}}\left(\mathrm{Cu}^{\mathrm{I}}\right)}\right)
$$

where $E^{0}=153 \mathrm{mV}$ (vs. SHE) is the standard reduction potential of $\mathrm{Cu}^{2+} / \mathrm{Cu}^{+}{ }^{29}$

\section{Results and discussion}

The N-terminal residues of $\mathrm{A} \beta$ peptides have a major impact on $\mathrm{Cu}$ (II) binding

Processing of the amyloid precursor protein (APP) by proteases $\beta$ - and $\gamma$-secretase generates the $A \beta$ peptides $1-(36-43)$ whose interaction with transition metal ions, and with copper, in particular, appears to be a source of toxicity in vivo. ${ }^{30}$ The possible effects include catalytic generation of reactive oxygen species (ROS) by toxic oligomers. ${ }^{2,31,32}$ All major $\mathrm{Cu}$ ligands are located within the first 16-residue water-soluble fragment and thus $A \beta 16$ is a valid model for the study of the copper chemistry of full length $A \beta .^{3}$ In particular, the $\mathrm{N}$-terminal amine nitrogen and nearby residues play a critical role in $\mathrm{Cu}(\mathrm{II})$ coordination and in imposing both binding affinity and coordination modes.

In this study, the two N-terminal residues Asp1 and Ala2 of A $\beta 16$ were changed systematically via generation of the following variants (Table 1$)$ :

(i) D1A eliminates the sidechain of residue 1 as a potential ligand ( $c f$. IA of Fig. 1b).

(ii) $\mathrm{D} 1 \mathrm{E}, \mathrm{D} 1 \mathrm{~N}$, and $\mathrm{D} 1 \mathrm{H}$ provide alternative residue 1 sidechains as potential ligands; D1H/H14A also removes His14 as a potential ligand.

(iii) A2P removes the amide of residue 2 as a potential anionic ligand ( $c f$. II of Fig. 1b).

In addition, the $\mathrm{N}$-terminus was acetylated (Ac-A $\beta 16)$ to perturb its metal binding properties. Detection of fine differences in properties is possible with a set of peptide-based dansyl fluorescent probes DP2-4 (Tables 1 and 2). ${ }^{21}$

A control titration of standardized $\mathrm{CuSO}_{4}$ solution with the DP2 probe alone generated a titration curve with an endpoint at $[\mathrm{Cu}(\mathrm{II})]_{\text {tot }} /[\mathrm{DP} 2]=1.0$ (Fig. $3 \mathrm{a}$ and $\mathrm{b}$, black trace), confirming that the probe binds a single $\mathrm{Cu}(\mathrm{II})$ ion of the highest affinity $\left(\log K_{\mathrm{D}}=-9.9\right) \cdot{ }^{21}$ The equivalent titration into a $1: 1$ mixture of DP2 and A $\beta 16(2.0 \mu \mathrm{M})$ in Mops buffer ( $50 \mathrm{mM}, \mathrm{pH}$ 7.4) generated a titration curve with an apparent endpoint at $[\mathrm{Cu}(\mathrm{II})]_{\mathrm{tot}} /[\mathrm{DP} 2] \sim 2.0$ (Fig. 3b, red trace). The essentially linear nature of the curve indicated that the peptide can bind one equiv. of $\mathrm{Cu}(\mathrm{II})$ with an affinity similar to that of DP2. Indeed, the $\mathrm{Cu}$ (II) binding sequence in the DP2 peptide was designed as a mimic of A $\beta 16$ (Table 1). ${ }^{21}$

Equivalent titrations for $\mathrm{A} \beta 16-\mathrm{D} 1 \mathrm{~A}$ and $\mathrm{A} \beta 16-\mathrm{D} 1 \mathrm{H}$ also displayed apparent titration endpoints at $[\mathrm{Cu}(\mathrm{II})]_{\text {tot }} /[\mathrm{DP} 2] \sim 2.0$ (Fig. 3b, green, blue), consistent with these peptides also binding a single $\mathrm{Cu}(\mathrm{II})$ ion. However, the different shapes of the titration curves are consistent with the affinity of $\mathrm{A} \beta 16$ being higher than that of $A \beta 16-D 1 A$ but lower than that of $A \beta 16-D 1 H$. In fact, the probe 
Table $2 \log K_{\mathrm{D}}^{\|}$for $\mathrm{Cu}(I)$ of $\mathrm{A} \beta 16$ peptide and variants at different $\mathrm{pH}$ values ${ }^{\mathrm{a}}$

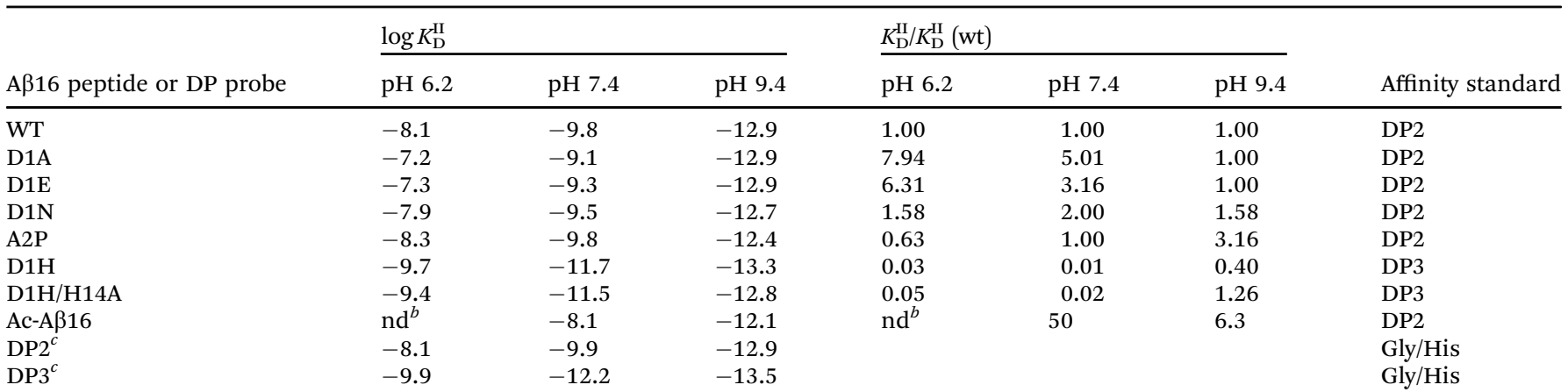

${ }^{a}$ The $\log K_{\mathrm{D}}^{\mathrm{II}}$ values were determined via ligand competition for $\mathrm{Cu}(\mathrm{II})$ between each peptide and the specified DP probe ligand in respective buffer $(50 \mathrm{mM})$ of Mes ( $\mathrm{pH}$ 6.2), Mops ( $\mathrm{pH} 7.4)$ and Ches ( $\mathrm{pH}$ 9.4). See the Experimental section for details. ${ }^{b}$ Too weak to be determined reliably. ${ }^{c}$ Following relationships demonstrated from a previous study ${ }^{21}$ were used to calculate the $\log K_{\mathrm{D}}^{\mathrm{II}}$ values given in the table: $\log K_{\mathrm{D}}^{\mathrm{HI}}=1.15-1.49 \mathrm{pH}$ for DP2 and eqn (5) with $K_{\mathrm{D}}^{\mathrm{abs}}$ and each $\mathrm{p} K_{\mathrm{a}}$ value given in Table 3 for DP3.

does not compete effectively with the latter peptide until $[\mathrm{Cu}(\mathrm{II})]_{\text {tot }} /[\mathrm{DP} 2] \sim 1$.

A more quantitative approach is possible with the fluorescence recovery analysis of titrations of apo-peptides into solutions of a copper-probe complex of appropriate affinity. Preliminary testing indicated that the appropriate experiments involved substoichiometric $\mathrm{Cu}(\mathrm{II})$ in the systems $\mathrm{Cu}_{0.9}^{\mathrm{II}}-\mathrm{DP} x(x=2$ for $\mathrm{A} \beta 16-$ $\mathrm{D} 1 \mathrm{~A}$ and 3 for $\mathrm{A} \beta 16-\mathrm{D} 1 \mathrm{H}$ and $x=2$ or 3 for $\mathrm{A} \beta 16$ ). Analysis of the results suggested that, at $\mathrm{pH} 7.4$, the $\mathrm{Cu}(\mathrm{II})$ binding affinity of $A \beta 16-D 1 A$ is 5 -fold weaker than that of $A \beta 16$ while the affinity of $\mathrm{A} \beta 16-\mathrm{D} 1 \mathrm{H}$ is $\sim 100$ times stronger (Fig. $3 \mathrm{c}-\mathrm{f}$ and Table 2).

Equivalent experiments and analyses for the remaining peptides, with their respective optimal DP probes, lead to an increasing order of relative $\mathrm{Cu}(\mathrm{II})$ binding affinities at $\mathrm{pH} 7.4$ as follows (Table 2):

$$
\begin{gathered}
\text { Ac-A } \beta 16(50)<\mathrm{A} \beta 16-\mathrm{D} 1 \mathrm{~A}(5.0)<\mathrm{A} \beta 16-\mathrm{D} 1 \mathrm{E}(3.2) \\
<\mathrm{A} \beta 16-\mathrm{D} 1 \mathrm{~N}(2.0)<\mathrm{A} \beta 16(1.0) \sim \mathrm{A} \beta 16-\mathrm{A} 2 \mathrm{P}(1.0) \\
<\mathrm{A} \beta 16-\mathrm{D} 1 \mathrm{H} / \mathrm{H} 14 \mathrm{~A}(0.02)<\mathrm{A} \beta 16-\mathrm{D} 1 \mathrm{H}(0.01)
\end{gathered}
$$

The numbers in the brackets refer to the dissociation constants normalized to that of $\mathrm{A} \beta 16$ and decrease in the order of increasing $\mathrm{Cu}(\mathrm{II})$ binding affinity. It is apparent that the residues in the $\mathrm{N}$-terminal region have a major impact on the binding affinity and likely on the binding mode as well. A more complete analysis follows.

\section{Component IA is favoured by the presence of a His1-based chelate ring}

The two most significant changes in $\mathrm{Cu}(\mathrm{II})$ binding affinity are seen for Ac-A $\beta 16$ and A $\beta 16-\mathrm{D} 1 \mathrm{H}$ (eqn (9)). The N-terminal amine nitrogen was blocked by acetylation in Ac-A $\beta 16$, leading to a significant decrease in affinity under all conditions (Table 2), confirming the primary anchoring role of the N-terminal nitrogen in $\mathrm{Cu}$ (II) binding for each of the components IA, IB and II. Replacement of the carboxylate sidechain of Asp1 with the imidazole sidechain of His1 in A $\beta 16-D 1 H$ led to an increase in affinity of almost two orders of magnitude at pH 7.4 (Table 2).
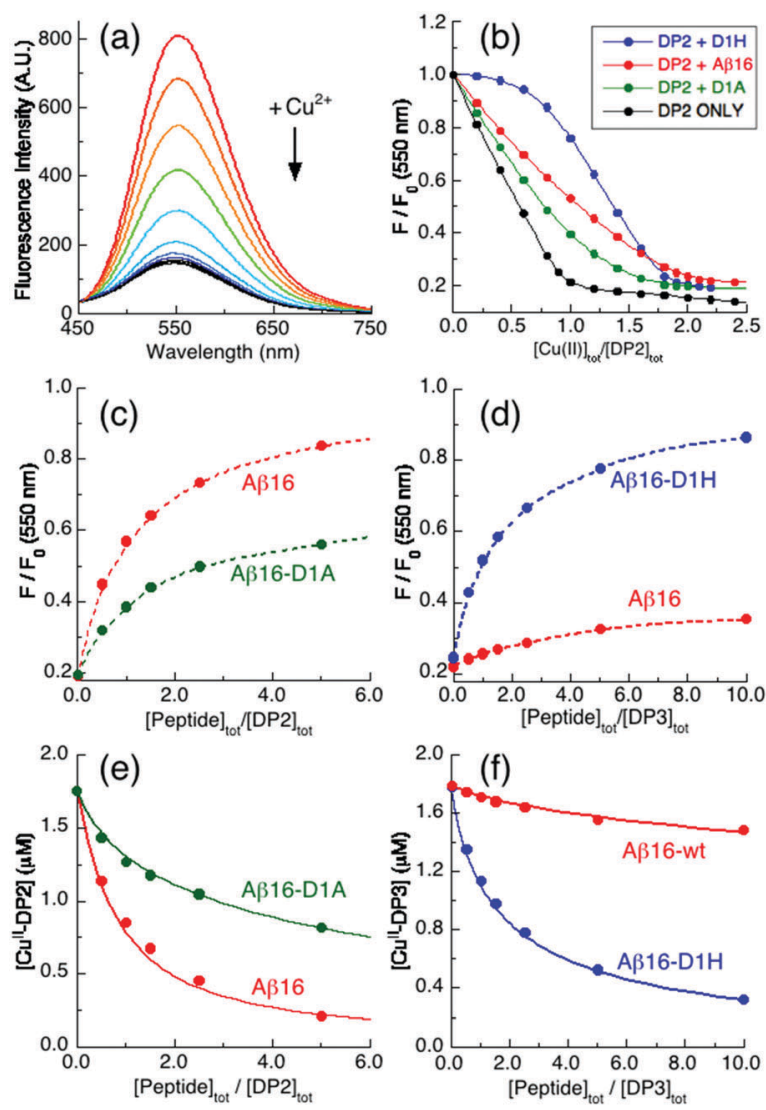

Fig. 3 Quantification of $\mathrm{Cu}(\mathrm{II})$ binding to $\mathrm{A} \beta 16$ peptides in Mops buffer $(50 \mathrm{mM}, \mathrm{pH}$ 7.4). (a) Illustrative quenching of the fluorescence spectrum of a DP2 probe $(2.0 \mu \mathrm{M})$ upon titration with $\mathrm{Cu}^{2+}$ solution $\left(\lambda_{\text {ex }}=330 \mathrm{~nm}\right.$; $\lambda_{\mathrm{em}}=550 \mathrm{~nm}$ ); (b) $\mathrm{Cu}^{2+}$ titration curves at $550 \mathrm{~nm}$ for $1: 1$ mixtures $(2.0 \mu \mathrm{M})$ of DP2 and AB16 peptides plus control with DP2 only; (c and d) recovery of the $\mathrm{Cu}(I)$-quenched fluorescence intensity of mixtures (c) $\mathrm{Cu}_{0.9}^{\prime \prime}-\mathrm{DP} 2$ or (d) $\mathrm{Cu}_{0.9}^{\prime \prime}-\mathrm{DP} 3(2.0 \mu \mathrm{M})$ upon titration with A 316 peptides; (e and f) correlation of (e) [Cull-DP2] versus [AB16 peptide $]_{\text {tot }} /[\mathrm{DP} 2]_{\text {tot }}$ or (f) $\left[C u^{\prime \prime}-D P 3\right]$ versus $[A \beta 16 \text { peptide }]_{\text {tot }} /[D P 3]_{\text {tot. }}$. The solid traces in (e and f) are the fits of eqn (3) to the experimental data, allowing estimation of the conditional log $K_{D}^{\| \prime}$ for the $\mathrm{Cu}(I)$ complex of each $\mathrm{A} \beta 16$ peptide in the range of $\mathrm{pH}$ values listed in Table 1. 
(a)

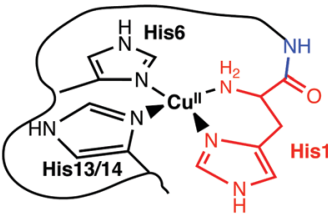

(i) Component IA for Cu"(Aß16-D1H)

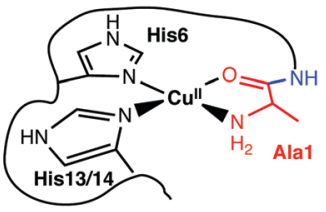

(ii) Component IB for Cull $(A \beta 16-D 1 A)$ (b)

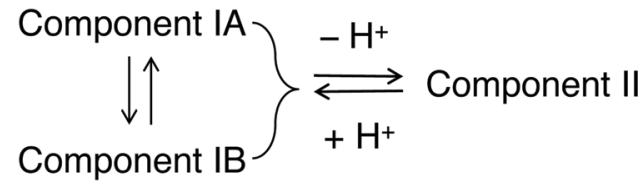

Fig. 4 Proposed $\mathrm{Cu}($ (I) coordination modes of $\mathrm{A} \beta 16$ peptides and variants. (a) Component IA for Cu'(Aß16-D1H) and component IB for Cu'(Aß16-D1A) (b) Equilibria between compoments IA, IB and II for Cu"(Aß16).

The presence of His1 allows the formation of a stabilizing bidentate ligand comprising the N-terminal amine and the His1 sidechain within a six-membered chelate ring. Other known examples of this binding mode include the DP3 probe employed in this work (Fig. 2a) and the bacterial copper binding proteins PcoC and CopC. $^{24,33-35}$ The $\mathrm{Cu}(\mathrm{II})$ coordination sphere in $\mathrm{Cu}^{\mathrm{II}}(\mathrm{A} \beta 16-\mathrm{D} 1 \mathrm{H})$ may be depicted schematically by Fig. $4 \mathrm{a}(\mathrm{i})$, noting its similarity to the proposed IA site in $A \beta 16$ (Fig. 1b). There are three other His residues (His-6, -13, -14) in the A 16 -D1H sequence, but only two of them are required to constitute the proposed $\mathrm{Cu}(\mathrm{II})$ site. In fact, replacing one of them (His14) with Ala in A $316-\mathrm{D} 1 \mathrm{H} / \mathrm{H} 14 \mathrm{~A}$ only marginally affects the $\mathrm{Cu}$ (II) affinity (Fig. 5a and Table 2).

The $\mathrm{Cu}(\mathrm{II})$ sites proposed above for $\mathrm{Cu}^{\mathrm{II}}(\mathrm{A} \beta 16-\mathrm{D} 1 \mathrm{H})$ and $\mathrm{Cu}^{\mathrm{II}}(\mathrm{A} \beta 16-\mathrm{D} 1 \mathrm{H} / \mathrm{H} 14 \mathrm{~A})$ are supported by the fact that the $\mathrm{pH}$-dependence of their affinities for $\mathrm{Cu}(\mathrm{II})$ (expressed as $\left.\mathrm{p} K_{\mathrm{D}}^{\mathrm{II}}=-\log K_{\mathrm{D}}^{\mathrm{II}}\right)$ can be modeled satisfactorily over the $\mathrm{pH}$ range
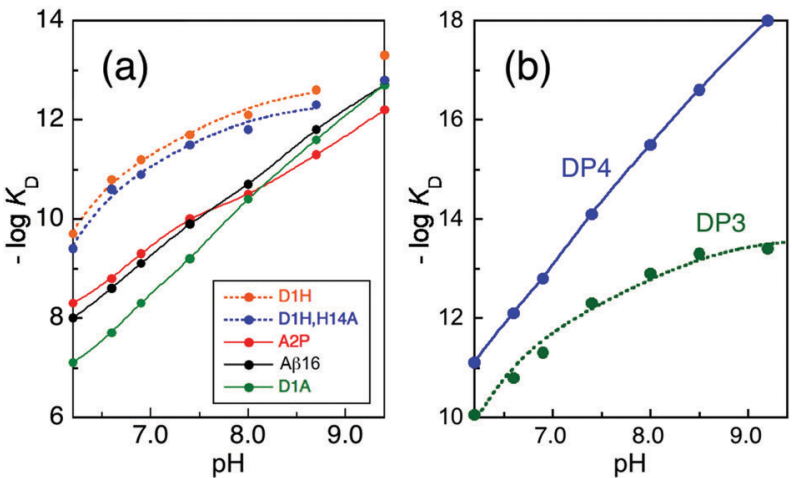

Fig. 5 Variation of conditional $\mathrm{p} K_{\mathrm{D}}^{\|}\left(=-\log K_{\mathrm{D}}^{\prime \prime}\right)$ with solution $\mathrm{pH}$ : (a) $\mathrm{Cu}(\mathrm{II})$ complexes of various A 1616 peptides (see Table S1 for the Experimental data, ESI†); (b) $\mathrm{Cu}(॥)$ complexes of DP3 and DP4 probe peptides (data adapted from ref. 21). The dotted traces for peptides $\mathrm{D} 1 \mathrm{H}, \mathrm{D} 1 \mathrm{H} / \mathrm{H} 14 \mathrm{~A}$ and DP3 are the curve-fittings of the respective experimental data to eqn (5) generating $K_{D}^{\text {abs }}$ and $\mathrm{p} K_{\mathrm{a}}$ for each ligand of the $\mathrm{Cu}\left({ }^{\prime \prime}\right)$ sites that are given in Table 3. Note: the data for $\mathrm{D} 1 \mathrm{H}$ and $\mathrm{D} 1 \mathrm{H} / \mathrm{H} 14 \mathrm{~A}$ above $\mathrm{pH} 8.7$ cannot be fitted to the model.
6.0-8.7, assuming that the dependence is driven by the basicity of the proposed ligands (Fig. 5a and eqn (5)). Their derived ligand $\mathrm{p} K_{\mathrm{a}}$ values are listed in Table 3 . The $\mathrm{I} \rightarrow$ II transition is not evident in these peptides and the $\mathrm{pH}$ dependence of the affinities is comparable to those of several documented examples including DP3 and several CopC proteins that adopt a DP3-type $\mathrm{Cu}(\mathrm{II})$ binding mode, shown in Fig. $2 \mathrm{a}^{21,33}$

In contrast, the absence of His1 in the WT, D1A and A2P peptides leads to very different $\mathrm{pH}$-dependencies that could not be modelled over the same $\mathrm{pH}$ range with any single set of ligands or a single binding mode (Fig. 5). The behaviour is attributed to the influence of the I $\rightarrow$ II transition, even for the A2P peptide at pH $>8.5$ (see Fig. 6c). The $\mathrm{Cu}$ (II) site of component II features a deprotonated peptide amide ligand (Fig. 1b).

$\mathrm{pH}$-Dependent EPR spectra provide further support for the proposed binding models. The EPR signal of $\mathrm{Cu}^{\mathrm{II}}(\mathrm{A} \beta 16-\mathrm{D} 1 \mathrm{H})$ shows no change within the $\mathrm{pH}$ range 5.9-8.9 and essentially superimposes that of $\mathrm{Cu}^{\mathrm{II}}-\mathrm{DP} 3$ (Fig. 6a and b). It differs significantly from the component I EPR signals of $\mathrm{Cu}^{\mathrm{II}}(\mathrm{A} \beta 16)$ or $\mathrm{Cu}^{\mathrm{II}}(\mathrm{A} \beta 16-\mathrm{A} 2 \mathrm{P})$ ( $c f$. , Fig. 6a-d and Table 4). This supports a $\mathrm{Cu}$ (II) site in $\mathrm{Cu}^{\mathrm{II}}(\mathrm{A} \beta 16-\mathrm{D} 1 \mathrm{H})$ of composition $\left[\mathrm{NH}_{2}, 3 \mathrm{~N}_{\mathrm{im}}\right]$ that features the stabilizing bidentate ligand comprising the $\mathrm{N}$-terminal amine and the His1 sidechain (Fig. 2a and 4a(i)).

This particular His1 sidechain binding mode is suppressed in $\mathrm{Cu}^{\mathrm{II}}$-DP4. Although its four-residue peptide sequence (His-LysHis-His) features a His1 residue, the presence of His3 provides the more favourable ATCUN binding mode that includes the $\mathrm{N}$-terminal amine and two intervening deprotonated backbone amides (Fig. 2b). ${ }^{21}$ This conclusion is supported by the dramatic pH-dependence of its $\mathrm{Cu}$ (II) binding affinity and the unique EPR signal: both are readily distinguishable from those of components I and II (Fig. 5b and 6f). ${ }^{21}$ This same ATCUN binding mode is adopted by the $\mathrm{N}$-truncated $\mathrm{A} \beta 16$ peptide, $\mathrm{A} \beta 4-16$ (sequence: FRHDSGYEVHHQK) that exhibits $\mathrm{Cu}(\mathrm{II})$ affinities and EPR spectra equivalent to those of DP4 (Table 4). ${ }^{16,21-23}$

\section{Component IB is favoured by an Ala1 $\mathrm{N}$-terminus at low $\mathrm{pH}$ but is less stable than IA}

The variant $\mathrm{A} \beta 16-\mathrm{D} 1 \mathrm{~A}$ has a five-fold lower affinity for $\mathrm{Cu}(\mathrm{II})$ than $\mathrm{A} \beta 16$ at pH 7.4 (eqn (9); Fig. 5a; Table 2). The I $\rightarrow$ II transition in $\mathrm{Cu}^{\mathrm{II}}(\mathrm{A} \beta 16)$ with $\mathrm{p} K_{\mathrm{a}} \sim 7.8$ is characteristic of deprotonation of the peptide amide of Ala2. The non-coordinating methyl sidechain of Ala1 eliminates the IA binding mode, enforcing a IB mode (Fig. $4 \mathrm{a}(\mathrm{ii})$ ) that is converted to component II at $\mathrm{pH} \sim 6.5$, i.e., $>1 \mathrm{pH}$ unit lower than that for the equivalent transition of $\mathrm{Cu}^{\mathrm{II}}(\mathrm{A} \beta 16)$ (Fig. 6d and e). However, at higher $\mathrm{pH}$ values, the affinities of $\mathrm{A} \beta 16$ and $\mathrm{A} \beta 16-\mathrm{D} 1 \mathrm{~A}$ for $\mathrm{Cu}(\mathrm{II})$ become indistinguishable (Fig. 5a), consistent with a common tridentate chelate $\left[-\mathrm{NH}_{2}, \mathrm{~N}^{-}, \mathrm{CO}\right]$ as part of the square planar array $\left[-\mathrm{NH}_{2}, \mathrm{~N}^{-}\right.$, $\mathrm{CO}, \mathrm{N}_{\mathrm{im}}$ ], characteristic of component II (Fig. 1b). The binding affinity of the latter shows a different $\mathrm{pH}$ dependency and EPR signal to those of DP4, a Cu(II) ligand of the ATCUN binding mode (Fig. 2b, 5 and 6).

The equivalent data for variants D1N and D1E provide further support for a role for Asp1 as an equatorial ligand: their $\mathrm{Cu}$ (II) binding properties are intermediate between those of $\mathrm{A} \beta 16$ and 
Table 3 Thermodynamic data of $\mathrm{Cu}(\|)$ sites derived from correlation of $\log K_{\mathrm{D}}$ and $\mathrm{pH}^{a}$

\begin{tabular}{|c|c|c|c|c|c|}
\hline \multirow[b]{2}{*}{ Peptide or protein } & \multirow[b]{2}{*}{$\mathrm{Cu}$ (II) binding site } & \multirow[b]{2}{*}{$\log K_{\mathrm{D}}^{\mathrm{abs}}$} & \multicolumn{2}{|c|}{$\mathrm{p} K_{\mathrm{a}}$ for } & \multirow[b]{2}{*}{ Ref. } \\
\hline & & & $\mathrm{NH}_{2}$ & $\mathrm{~N}^{\mathrm{Im}}$ & \\
\hline Aß16-D1H & $\mathrm{NH}_{2}$ (H1); $3 \mathrm{~N}^{\mathrm{Im}}(\mathrm{H} 1,6,13 / 14)$ & -12.7 & 8.3 & 6.4 & This work \\
\hline $\mathrm{A} \beta 16-\mathrm{D} 1 \mathrm{H} / \mathrm{H} 14 \mathrm{~A}$ & $\mathrm{NH}_{2}(\mathrm{H} 1) ; 3 \mathrm{~N}^{\operatorname{Im}}(\mathrm{H} 1,6,13)$ & -12.3 & 8.1 & 6.4 & This work \\
\hline DP3 probe & $\mathrm{NH}_{2}(\mathrm{H} 1), 3 \mathrm{~N}^{\mathrm{Im}}(\mathrm{H} 1,5,7)$ & -13.6 & 8.8 & 6.5 & 21 \\
\hline Pf-CopC & $\mathrm{NH}_{2}(\mathrm{H} 1) ; 3 \mathrm{~N}^{\mathrm{Im}}(\mathrm{H} 1,3,85)$ & -17.2 & 8.8 & 6.6 & 33 \\
\hline Ps-CopC & $\mathrm{NH}_{2}$ (H1); $2 \mathrm{~N}^{\mathrm{Im}}(\mathrm{H} 1,91) ; \mathrm{COO}^{-}$(D89) & -14.4 & 8.2 & 6.1 & 33 \\
\hline Ec-PcoC & $\mathrm{NH}_{2}(\mathrm{H} 1) ; 2 \mathrm{~N}^{\operatorname{Im}}(\mathrm{H} 1,92) ; \mathrm{COO}^{-}$(D90) & -14.0 & 8.2 & 6.5 & 33 \\
\hline
\end{tabular}

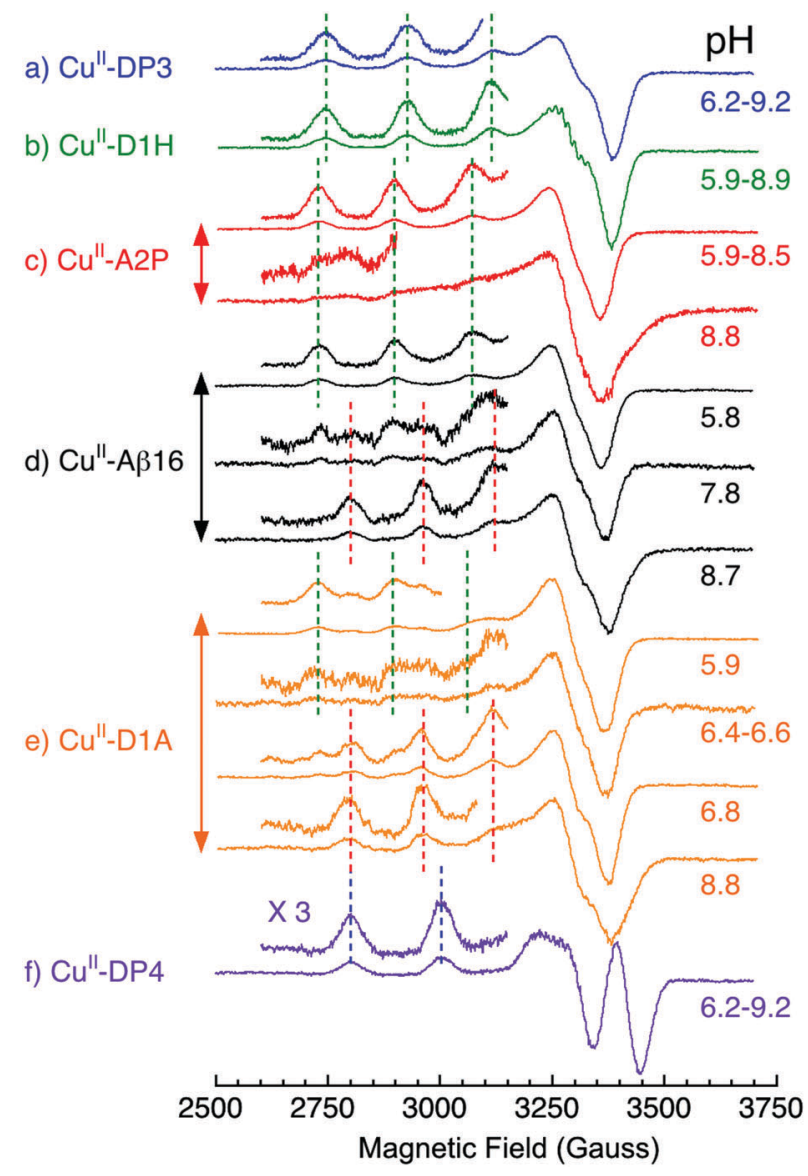

Fig. 6 Frozen solution EPR spectra of various $\mathrm{Cu}($ II) complexes recorded

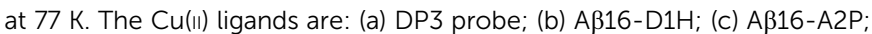
(d) $A \beta 16$; (e) $A \beta 16-D 1 A$; (f) DP4 probe at various $\mathrm{pH}$ values as indicated (see the Experimental section for detail). Insets show enlargements of the spectra scaled up by a factor of 3 . Component I is indicated by green dashed lines and component II by red dashed lines.

D1A (Table 2 and Fig. S1-S4, ESI $\dagger$ ). The data are consistent with the weaker ligand properties of the sidechains of Asn1 (neutral carboxamide is a poor ligand for $\mathrm{Cu}(\mathrm{II})$ ) and Glu1 (which would form a less favoured seven-membered chelate ring). In particular, substitution of Asp1 with Asn or Glu also leads to a decrease in $\mathrm{Cu}(\mathrm{II})$ binding affinity (Table 2 ) and in the $\mathrm{p} K_{\mathrm{a}}$ for the I $\rightarrow$ II transition (Fig. S1 and S4, $\mathrm{ESI}^{\dagger}$ ).

Several previous studies provide support for this model. Deletion of Asp1 in A $\beta 16$ generates a truncated peptide with
Table 4 EPR parameters derived from frozen solution spectra ${ }^{a}$

\begin{tabular}{|c|c|c|c|c|c|c|c|}
\hline \multirow{2}{*}{$\begin{array}{l}\text { Ligand for the } \\
\mathrm{Cu}^{\mathrm{II}} \text { complex }\end{array}$} & \multicolumn{3}{|c|}{ Component I } & \multicolumn{3}{|c|}{ Component II } & \multirow{2}{*}{$\begin{array}{l}\mathrm{p} K_{\mathrm{a}} \text { for } \\
\mathrm{I} \leftrightarrow \mathrm{II} \\
\end{array}$} \\
\hline & $g_{\|}$ & $g_{\perp}$ & $A_{\|}(\mathrm{G})$ & $g_{\|}$ & $g_{\perp}$ & $A_{\|}(\mathrm{G})$ & \\
\hline DP3 & $2.242^{b}$ & $2.060^{b}$ & $182^{b}$ & - & - & - & - \\
\hline $\mathrm{A} \beta 16-\mathrm{D} 1 \mathrm{H}^{c}$ & 2.243 & 2.060 & 183 & - & - & - & - \\
\hline Aß16-A2P & 2.269 & 2.051 & 169 & - & - & - & $\sim 8.8$ \\
\hline $\mathrm{A} \beta 16$ & 2.268 & 2.050 & 170 & 2.202 & 2.042 & 160 & $\sim 7.8$ \\
\hline$A \beta 16-D 1 A$ & 2.269 & 2.051 & 169 & 2.204 & 2.041 & 161 & $\sim 6.5$ \\
\hline$A \beta 2-16$ & $2.264^{d, e}$ & - & $170^{d, e}$ & $2.226^{d}$ & - & $153^{d}$ & - \\
\hline DP4 & - & - & - & $2.178^{b}$ & $2.050^{b}$ & $200^{b}$ & - \\
\hline A $\beta 4-16$ & - & - & - & $2.178^{d}$ & $2.049^{d}$ & $206^{d}$ & - \\
\hline
\end{tabular}

${ }^{a}$ Estimated directly from the respective spectrum, see Fig. 6, Fig. S1-S7 (ESI) for details. ${ }^{b}$ Data adopted from ref. $21 .{ }^{c}$ Data for $\mathrm{Cu}^{\mathrm{II}}(\mathrm{A} \beta 16-\mathrm{D} 1 \mathrm{H} /$ H14A) were indistinguishable (see Fig. S5 and S6, ESI). ${ }^{d}$ Data adopted from ref. 16. ${ }^{e}$ Minor component at $\mathrm{pH}$ 7.4.

an Ala N-terminus (sequence: AEFRHDSGYEVHHQK). Its qualitative $\mathrm{Cu}$ (II) binding properties are comparable to those of D1A: weaker binding affinity for $\mathrm{Cu}$ (II) and a lower I $\rightarrow$ II transition $\mathrm{p} K_{\mathrm{a}}{ }^{16}$ Similar effects were also observed for D1N, ${ }^{17-19}$ although the decreased $\mathrm{p} K_{\mathrm{a}}$ was attributed to the change of a putative hydrogen bond to the $\mathrm{Cu}(\mathrm{II})$ ligand. $^{17}$

\section{Component $\mathrm{I}$ is favoured in $\mathrm{Cu}^{\mathrm{II}}(\mathrm{A} 2 \mathrm{P})$}

The I $\rightarrow$ II transition relies on the availability of the Asp1-Ala2 peptide amide (Fig. 1b). Substitution of Ala2 with Pro eliminates this possibility and all properties observed for $\mathrm{Cu}^{\mathrm{II}}(\mathrm{A} 2 \mathrm{P})$ are consistent with the binding mode being locked in component I. Most obviously, $K_{\mathrm{D}}$ is comparable to that of $\mathrm{Cu}^{\mathrm{II}}(\mathrm{A} \beta 16)$ at lower $\mathrm{pH}$ values but becomes larger (i.e., lower affinity) at higher $\mathrm{pH}$ with the point of deviation occurring above $\mathrm{pH} 7.8$, in line with the I $\rightarrow$ II transition for $\mathrm{Cu}^{\mathrm{II}}(\mathrm{A} \beta 16)$ around this $\mathrm{pH}$ (Fig. 5a and $6 \mathrm{~d})$. The EPR signal confirmed that component I of $\mathrm{Cu}^{\mathrm{II}}(\mathrm{A} \beta 16-\mathrm{A} 2 \mathrm{P})$ was present up to at least pH 8.5 (Fig. 6c).

\section{At lower $\mathrm{pH}$, component IA is preferred for $\mathrm{A} \beta$ peptides with an Asp1 N-terminus}

The $\mathrm{Cu}(\mathrm{II})$ affinities of component I of $\mathrm{Cu}^{\mathrm{II}}(\mathrm{A} \beta 16)$ and $\mathrm{Cu}^{\mathrm{II}}(\mathrm{A} \beta 16$ $\mathrm{A} 2 \mathrm{P})$ are similar. They are about one order of magnitude higher than that of component IB, which is favoured for $\mathrm{Cu}^{\mathrm{II}}(\mathrm{A} \beta 16$ D1A) at lower pH values such as pH 6.2 (Fig. 5a and Table S1, ESI $\dagger)$. This implies that component IA rather than IB is the preferred binding mode for both $\mathrm{Cu}^{\mathrm{II}}(\mathrm{A} \beta 16)$ and $\mathrm{Cu}^{\mathrm{II}}(\mathrm{A} \beta 16-\mathrm{A} 2 \mathrm{P})$ at lower $\mathrm{pH}$ values (Fig. 1b). This is consistent with the 
negatively charged harder carboxylato ligand favouring the harder metal ion $\mathrm{Cu}$ (II) over a neutral peptide carbonyl oxygen for similar stereochemistries (a six-membered chelate ring in IA versus a five-membered chelate ring in IB; see Fig. 1b).

However, the possibility for a IB binding mode for either $\mathrm{Cu}^{\mathrm{II}}(\mathrm{A} \beta 16)$ or $\mathrm{Cu}^{\mathrm{II}}(\mathrm{A} \beta 16-\mathrm{A} 2 \mathrm{P})$ at low $\mathrm{pH}$ cannot be excluded. The EPR signals for both components IA and IB are indistinguishable (Fig. 6c-e and Table 4) and cannot be used to differentiate the binding modes at low $\mathrm{pH}$. It is possible that components IA and IB are in fast exchange at lower $\mathrm{pH}$ for those peptides with an Asp1 N-terminus but with IA being the preferred binding mode. At higher $\mathrm{pH}$, both components IA and IB are converted to component II: the $K_{\mathrm{D}}$ values of $\mathrm{Cu}^{\mathrm{II}}(\mathrm{A} \beta 16)$ and $\mathrm{Cu}^{\mathrm{II}}(\mathrm{A} \beta 16-\mathrm{D} 1 \mathrm{~A})$ become indistinguishable at $\mathrm{pH} 9.4$ (Fig. 5a). But the I $\rightarrow$ II conversion is restricted for $\mathrm{Cu}^{\mathrm{II}}(\mathrm{A} \beta 16-\mathrm{A} 2 \mathrm{P})$, weakening its $\mathrm{Cu}$ (II) binding affinity at high $\mathrm{pH}$ relative to other $\mathrm{A} \beta 16$ peptides (Fig. 5a).

It is unlikely that the differences in the properties of $\mathrm{Cu}^{\mathrm{II}}(\mathrm{A} \beta 16)$, $\mathrm{Cu}^{\mathrm{II}}(\mathrm{A} \beta 16-\mathrm{A} 2 \mathrm{P})$ and $\mathrm{Cu}^{\mathrm{II}}(\mathrm{A} \beta 16-\mathrm{D} 1 \mathrm{~A})$ at lower $\mathrm{pH}$ values are due to axial coordination by the Asp1 sidechain due to the following reasons:

(i) Given the possibility of axial coordination, mutation of Asp1 by Ala should lower the affinity across the whole $\mathrm{pH}$ range. However, there is no difference in the $\mathrm{Cu}$ (II) affinity for component II between WT and D1A.

(ii) A bidentate $\left[\mathrm{NH}_{2}, \mathrm{COO}^{-}\right]$binding mode for peptides with $\mathrm{N}$-terminal aspartyl residues has been well-documented in many cases, including various $A \beta$ peptides. ${ }^{11,36,37}$

(iii) The IA binding mode is confirmed for many peptides and proteins with a His1 N-terminus including A $\beta 16-D 1 H, D P 3$ probe, CopC and PcoC proteins, as surveyed above.

(iv) Contributions from axial coordination at $\mathrm{Cu}$ (II) centres are usually negligible due to the Jahn-Teller effect. There are many possible carboxylate sidechains (Asp1, Asp7, Glu3 or Glu11) which have been proven to be redundant. For example, an E3Q mutation showed no significant effect on the EPR spectrum. ${ }^{3}$

The IA coordination mode for $\mathrm{A} \beta 16$ has been proposed frequently as one of the two possible coordination modes of Asp1 at lower $\mathrm{pH}$ for component I (Fig. 1b). ${ }^{9-11}$ However, component IB has been preferred recently, based mainly on pulsed EPR studies. ${ }^{4,12,13}$ The chemical and spectroscopic study presented in this work, supported by previous $\mathrm{Cu}(\mathrm{II})$ binding studies for those peptides with $\mathrm{N}$-terminal aspartyl residues, ${ }^{11,36}$ provides strong evidence that the preferred binding mode for component I in $\mathrm{Cu}^{\mathrm{II}}(\mathrm{A} \beta 16)$ is IA, and not IB (Fig. 1b). It is recommended that the possibility of the IB binding mode can be re-investigated by pulsed EPR using $\mathrm{Cu}^{\mathrm{II}}(\mathrm{A} \beta 16-\mathrm{D} 1 \mathrm{H})$ and $\mathrm{Cu}^{\mathrm{II}}(\mathrm{A} \beta 16-\mathrm{D} 1 \mathrm{~A})$ as controls.

\section{Impact of $\mathrm{N}$-terminal modification on $\mathrm{Cu}(\mathrm{I})$ binding}

The first evidence of $\mathrm{Cu}(\mathrm{I})$ binding to $\mathrm{A} \beta$ peptides was implicated in an early study of $\mathrm{Cu}(\mathrm{II})$ potentiation of $\mathrm{A} \beta$ neurotoxicity. ${ }^{38} \mathrm{We}$ now know that $\mathrm{A} \beta$ peptides bind $\mathrm{Cu}(\mathrm{I})$ mainly via a combination of two histidine residues within the first 16 residues. ${ }^{7,8}$ The $\mathrm{Cu}(\mathrm{I})$ binding stoichiometries and affinities of various $A \beta 16$ peptides generated in this work were examined using $\mathrm{Cu}(\mathrm{I})$ probe ligands Ferene S (Fs) and Ferrozine (Fz) according to a recent protocol. ${ }^{26}$
Both probe ligands react with $\mathrm{Cu}(\mathrm{I})$ under reducing conditions to yield respective chromophoric $\mathrm{Cu}(\mathrm{I})$ complexes $\left[\mathrm{Cu}^{\mathrm{I}} \mathrm{L}_{2}\right]^{3-}$ with different formation constants $\left(\log \beta_{2}=13.7\right.$ for $\mathrm{L}=\mathrm{Fs}$ and 15.1 for $\mathrm{L}=\mathrm{Fz}){ }^{26}$ They were used to estimate the binding stoichiometries of A $\beta 16$ peptides according to eqn (6) under weakly competing conditions and the binding affinities according to eqn (6) and (7) under strongly competing conditions. As demonstrated previously for $\mathrm{A} \beta 16,{ }^{8}$ most peptides listed in Table 1 bind a single equiv. of $\mathrm{Cu}(\mathrm{I})$ under $\mathrm{Cu}^{+}$limiting conditions imposed by a slight excess of the weak probe ligand Fs (Fig. 7a). The exception was A $\beta 16-\mathrm{D} 1 \mathrm{H}$ that appeared to bind more than one equiv. $\mathrm{Cu}(\mathrm{I})$ under the same conditions (Fig. 7b).

Increasing Fs ligand concentration or employing the stronger ligand $\mathrm{Fz}$ created more effective competing conditions for eqn (6) that allowed analysis and definition of $\mathrm{Cu}(\mathrm{I})$ binding affinity of each peptide with eqn (7) (Fig. 7c and d). There are only marginal differences in $\mathrm{Cu}(\mathrm{I})$ binding affinities for those peptide variants with substitution of a non-His residue in the sequence. But, the $\mathrm{Cu}(\mathrm{I})$ binding affinities of $\mathrm{A} \beta 16-\mathrm{D} 1 \mathrm{H}$ and $\mathrm{A} \beta 16-\mathrm{D} 1 \mathrm{H} / \mathrm{H} 14 \mathrm{~A}$ are slightly higher than those of the other peptides (Table 5).

The data are consistent with previous observations: (i) the non-His residues in the N-terminal region play little role in $\mathrm{Cu}(\mathrm{I})$ binding; ${ }^{8}$ (ii) two and only two His ligands are required for the flexible $\mathrm{A} \beta 16$ peptides to constitute a $\mathrm{Cu}(\mathrm{I})$ binding site (Fig. 1a); ${ }^{7,8,39-41}$ (iii) the $\mathrm{Cu}(\mathrm{I})$ bound by $\mathrm{A} \beta 16$ peptides is
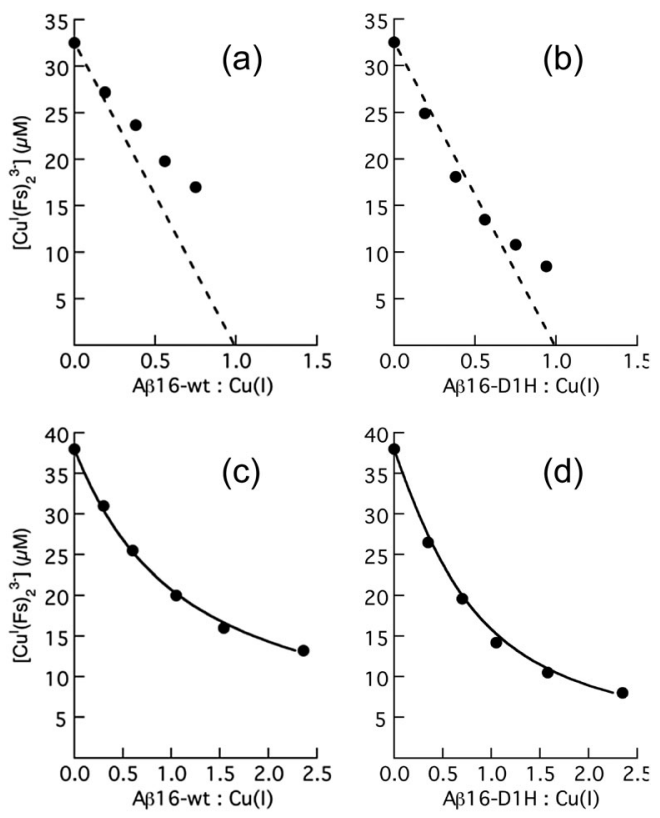

Fig. 7 Change in $\left[\mathrm{Cu}^{\prime}(\mathrm{Fs})_{2}\right]^{3-}$ concentration in Mops buffer $(50 \mathrm{mM}$, $\mathrm{pH} 7.4,1.0 \mathrm{mM} \mathrm{NH}_{2} \mathrm{OH}$ ) with increasing concentration of apo-peptide $A \beta 16$ ( $a$ and $c$ ) or $\mathrm{A} \beta 16-\mathrm{D} 1 \mathrm{H}$ ( $\mathrm{b}$ and $\mathrm{d}$ ) under weak competing conditions for (a and b) $\left([\mathrm{Cu}]_{\text {tot }}=32.5 \mu \mathrm{M}\right.$; $\left.[\mathrm{Fs}]_{\text {tot }}=70 \mu \mathrm{M}\right)$ or strong competing conditions for $(\mathrm{c}$ and $\mathrm{d})\left([\mathrm{Cu}]_{\text {tot }}=38.0 \mu \mathrm{M}\right.$; $\left.[\mathrm{Fs}]_{\text {tot }}=140 \mu \mathrm{M}\right)$. The dashed lines in ( $a$ and $b$ ) suggest $\mathrm{Cu}(\mathrm{I})$ binding stoichiometry under weak competing conditions; the solid traces in (c and d) are the curve-fitting of the experimental data to eqn (7), allowing estimation of the $\mathrm{Cu}(\mathrm{I})$ binding affinity for each peptide (Table 5). 
Table $5 \log K_{\mathrm{D}}^{\prime}$ for $\mathrm{Cu}\left(\right.$ (I) of $\mathrm{A} \beta 16$ peptide variants at different $\mathrm{pH}$ values ${ }^{\mathrm{a}}$

\begin{tabular}{|c|c|c|c|c|c|c|c|}
\hline $\mathrm{A} \beta 16$ peptide & \multicolumn{3}{|l|}{$\underline{\log K_{\mathrm{D}}^{\mathrm{I}}}$} & \multicolumn{3}{|c|}{$\underline{K_{\mathrm{D}}^{\mathrm{I}} / K_{\mathrm{D}}^{\mathrm{I}}(\mathrm{wt})}$} & Probe-affinity std \\
\hline WT & -9.6 & -10.6 & -11.0 & 1.00 & 1.00 & 1.00 & Fs \\
\hline D1E & -9.5 & -10.4 & -10.9 & 1.26 & 1.58 & 1.26 & Fs \\
\hline D1N & -9.5 & -10.4 & -10.8 & 1.26 & 1.58 & 1.58 & Fs \\
\hline $\mathrm{A} 2 \mathrm{P}$ & -9.9 & -10.7 & -11.0 & 0.50 & 0.79 & 1.00 & Fs \\
\hline $\mathrm{D} 1 \mathrm{H}$ & -10.2 & -11.1 & -11.5 & 0.25 & 0.32 & 0.32 & $\mathrm{Fz}$ \\
\hline
\end{tabular}

${ }^{a}$ The $\log K_{\mathrm{D}}^{\mathrm{I}}$ values were determined via ligand competition for $\mathrm{Cu}(\mathrm{I})$ between each peptide and the specified probe ligands Fs and/or Fz in the respective buffers (50 mM) Mes (pH 6.2), Mops (pH 7.4) and Ches ( $\mathrm{pH}$ 9.4). See the Experimental section for details.

populated between different pairs of His ligands in a fast exchange mode that tends to increase the apparent binding affinities. ${ }^{7,8}$ There are three different combinations of His pairs for most peptides examined in this work (Fig. 1a) and little difference in their $\mathrm{Cu}(\mathrm{I})$ binding properties, except that for $\mathrm{A} \beta 16-\mathrm{D} 1 \mathrm{H} / \mathrm{H} 14 \mathrm{~A}$ is slightly higher (Table 5).

A $\beta 16-D 1 H$ contains an extra His1 residue to provide four possible His ligands. Its $\mathrm{Cu}(\mathrm{I})$ affinity is the highest of all the peptides. Theoretically, it may bind two equiv. of $\mathrm{Cu}(\mathrm{I})$ with similar affinities, but this does not seem to be the case (Fig. 7b). Binding of the first equiv. of $\mathrm{Cu}(\mathrm{I})$ appears to discourage the binding of a second equiv. of $\mathrm{Cu}(\mathrm{I})$ with the same affinity (Fig. 7b). Certainly, the first equiv. of $\mathrm{Cu}(\mathrm{I})$ bound in $\mathrm{A} \beta 16-\mathrm{D} 1 \mathrm{H}$ may be populated among six different combinations of His pairs with considerable entropic gain, but binding of a further equiv. of $\mathrm{Cu}(\mathrm{I})$ is expected to restrict the binding sites to two His pairs only with considerable entropic loss.

\section{Impact of the $\mathbf{N}$-terminal modifications on the catalytic aerobic} oxidation of ascorbate

A common feature in Alzheimer's disease is oxidative stress, a component of which may result from undesirable catalytic reduction of dioxygen by cellular reductants such as ascorbate (Asc) mediated by $\mathrm{Cu}$ complexes of $\mathrm{A} \beta$ peptides. ${ }^{2,31,32,38,46-48}$ The dioxygen reduction product $\mathrm{H}_{2} \mathrm{O}_{2}$ is liable to undergo further reduction via Fenton-type reactions to generate the hydroxyl radical that can cause damage not only to the direct copper ligands ${ }^{49}$ but also to the surrounding residues. ${ }^{50}$ Indeed, Asc is abundant in the brain as an important neuromodulator and/or a neuroprotective agent and its concentration fluctuates dynamically in the range $200-400 \mu \mathrm{M}$ in certain synaptic clefts. ${ }^{51,52}$ In reality, the oxidation rate of Asc by dioxygen is slow and must be catalysed by redox-active couples such as $\mathrm{Cu}(\mathrm{II}) / \mathrm{Cu}(\mathrm{I})$. It has been proposed that metal dyshomeostasis in the Alzheimer brain may result in binding of copper to $\mathrm{A} \beta$ peptides to initiate catalytic roles. ${ }^{53}$

$\mathrm{A} \beta$ peptides can bind $\mathrm{Cu}(\mathrm{II})$ with the distinct binding modes of components I (including IA and IB) and II at physiological pH (Fig. 1b). Recent studies suggest that the different components available in $\mathrm{Cu}-\mathrm{A} \beta 16$ systems (Fig. 1) display different reaction kinetics in both metal substitution and redox chemistry. ${ }^{5,6}$ This study has identified the critical role of the first two N-terminal residues in determining these $\mathrm{Cu}(\mathrm{II})$ binding modes and an integrated study of the thermodynamic and kinetic contributions of these binding modes in the generation of $\mathrm{H}_{2} \mathrm{O}_{2}$ via catalytic aerobic oxidation of Asc was also undertaken. It should be noted that the reaction scheme in Fig. $8 \mathrm{a}$ is presented as an overall twoelectron reaction process, but it may proceed via two consecutive one-electron steps with $\mathrm{O}_{2}{ }^{--}$as an immediate reduction intermediate that may be reduced further to $\mathrm{H}_{2} \mathrm{O}_{2}$ by a second $\mathrm{Cu}^{\mathrm{I}}-\mathrm{A} \beta$ complex. ${ }^{54}$

The experiments were performed in air-saturated buffers $(50 \mathrm{mM}$ ) at three different $\mathrm{pH}$ values (Mops buffer at $\mathrm{pH} 6.6$ and 7.4; Ches buffer at $\mathrm{pH}$ 8.7). The catalytic aerobic oxidation of Asc $(50 \mu \mathrm{M})$ was undertaken with each $\mathrm{Cu}-\mathrm{A} \beta 16$ complex (prepared with a one-fold excess of apo-peptide) at a range of concentrations $(1.0-20 \mu \mathrm{M})$. The reaction was followed by the rate of decrease in absorbance at $265 \mathrm{~nm}$ for the reduced form of Asc (Fig. 8a). The catalytic activity of each $\mathrm{Cu}-\mathrm{A} \beta 16$ peptide complex was determined from the slope of a linear correlation (a)

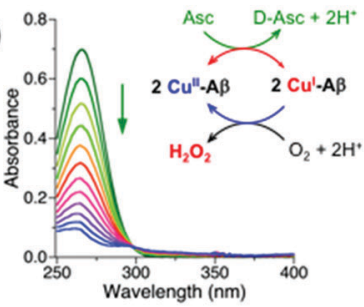

(c)

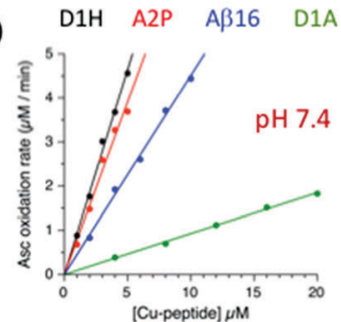

(b)

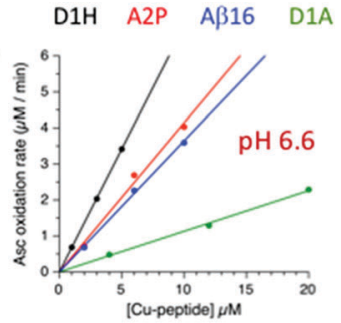

(d)

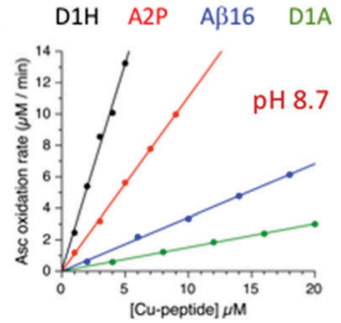

Fig. 8 (a) Catalytic aerobic oxidation of Asc monitored via A(265). Inset: Overall catalytic scheme. (b and c) Oxidation rate $\left(\mu \mathrm{M} \mathrm{min}{ }^{-1}\right.$ ) catalyzed by various $\mathrm{Cu}-\mathrm{A} \beta 16$ peptide complexes $(1-20 \mu \mathrm{M})$ in the presence of onefold excess of each respective apo-peptide in air-saturated buffers: (b) Mops buffer (50 mM, pH 6.6); (c) Mops buffer (50 mM, pH 7.4); (d) Ches buffer ( $50 \mathrm{mM}, \mathrm{pH}$ 8.7). The background oxidation rate (if any) that was detected in the presence of various concentrations of respective apopeptides without added $\mathrm{Cu}$ has been removed from the determined rate. 
of the initial oxidation rates versus the catalyst concentrations and expressed as $\mu \mathrm{M}$ Asc oxidized $/ \mu \mathrm{M}$ catalyst per minute, i.e., molar turnover number $\min ^{-1}$ (see the Experimental section for details).

As observed previously, ${ }^{8,55}$ Asc is stable in metal-free airsaturated buffers within the experiment timescale (1-2 h) and all apo-peptides are inactive (at least after demetallation with EDTA). 'Free' $\mathrm{Cu}^{2+}$ and $\mathrm{Cu}^{+}$have robust catalytic activities that are suppressed, but not silenced, by apo-peptides. The $\mathrm{Cu}-\mathrm{A} \beta 16$ complexes are redox-active catalysts, but less active than 'free' copper. A one-fold excess of apo-peptide over each $\mathrm{Cu}$-peptide was sufficient to minimize the catalytic contribution from 'free' $\mathrm{Cu}$ and to allow reliable detection of the catalytic activity of the $\mathrm{Cu}$-complex. The results are summarized in Fig. 8, Fig. S8 (ESI $\dagger$ ) and Table 6.

At $\mathrm{pH}$ 7.4, the molar catalytic activities $\left(\mathrm{min}^{-1}\right)$ of the different $\mathrm{Cu}-\mathrm{A} \beta 16$ complexes for Asc oxidation are given below in increasing order of their activity:

$$
\begin{gathered}
\mathrm{D} 1 \mathrm{~A}\left(0.08 \mathrm{~min}^{-1}\right) \sim \mathrm{D} 1 \mathrm{E}(0.10) \sim \mathrm{D} 1 \mathrm{~N}(0.14)<\mathrm{wt}(0.38) \\
<\mathrm{A} 2 \mathrm{P}(0.66)<\mathrm{D} 1 \mathrm{H}(0.78) \sim \mathrm{D} 1 \mathrm{H} / \mathrm{H} 14 \mathrm{~A}(0.9)
\end{gathered}
$$

As discussed above, the binding modes and affinities of these peptides are similar for $\mathrm{Cu}(\mathrm{I}$ ) (with minor difference for $\mathrm{A} \beta 16-\mathrm{D} 1 \mathrm{H}$ and $\mathrm{A} \beta 16-\mathrm{D} 1 \mathrm{H} / \mathrm{H} 14 \mathrm{~A})$ but differ considerably for $\mathrm{Cu}(\mathrm{II})$. On the one hand, replacement of Asp1 with Ala, Glu or Asn leads to destabilization of component IA inducing the I $\rightarrow$ II transition at lower $\mathrm{pH}$ (Table 4 and Fig. 6). On the other hand, substitution of Ala2 with Pro suppresses the transition while substitution of Asp1 by His1 further stabilizes the IA mode (Fig. 4a(i)). The observed reactivity order of eqn (10) clearly indicates that $\mathrm{Cu}$ sites accommodating a component I type $\mathrm{Cu}$ centre possess higher redox catalytic activity than those adopting a component II binding mode only. The conclusion applies to both $\mathrm{pH} 6.6$ and 8.7 (Table 6; Fig. 8 and Fig. S8, ESI $\dagger$ ).
However, contradictions to these conclusions can be seen in Table 6. For example, while components IA and II dominate at pH 6.6 and 8.7, respectively, for $\mathrm{Cu}^{\mathrm{II}}(\mathrm{A} \beta 16)$, they are both present in equilibrium at $\mathrm{pH} 7.4$ (Fig. 6d and Fig. S1, ESI $\dagger$ ), but the observed activities at $\mathrm{pH} 7.4$ and 8.7 were essentially identical (Table 6). The complications arise from the fact that Asc is more stable towards oxidation at lower $\mathrm{pH}$ and less stable at higher $\mathrm{pH}$ values. Hence, there are two opposing effects acting on the Asc oxidation rates: (i) a transition from component I at lower $\mathrm{pH}$ to component II at higher $\mathrm{pH}$ decreases the catalytic rate; (ii) deprotonation of Asc that occurs at higher $\mathrm{pH}$ increases its oxidation rate. This latter effect is seen clearly for $\mathrm{Cu}(\mathrm{A} \beta 16$ $\mathrm{A} 2 \mathrm{P}), \mathrm{Cu}(\mathrm{A} \beta 16-\mathrm{D} 1 \mathrm{H})$ and $\mathrm{Cu}(\mathrm{A} \beta 16-\mathrm{D} 1 \mathrm{H} / \mathrm{H} 14 \mathrm{~A})$. Within the $\mathrm{pH}$ range 6-9, component IA dominates in the first complex and is locked in place in the latter two complexes (Fig. $6 \mathrm{~b}$ and c). However, the catalytic oxidation rate increased with $\mathrm{pH}$ for each complex.

To separate these two opposing effects, the observed oxidation rates were normalized to that of $\mathrm{Cu}(\mathrm{A} \beta 16-\mathrm{D} 1 \mathrm{H})$ under the same conditions (Table 6). The normalized data indicate: (i) the redox activities of $A \beta 16$ and variants $A \beta 16-D 1 A,-D 1 E$ and -D1N decrease uniformly with increasing $\mathrm{pH}$, consistent with the influence of the I $\rightarrow$ II transition (Fig. 6d, e and Fig. S1-S4, ESI $\dagger$ ); (ii) the redox activity of $\mathrm{Cu}(\mathrm{A} \beta 16-\mathrm{A} 2 \mathrm{P})$ is lowest at $\mathrm{pH} 8.7$, consistent with a partial transition of the $\mathrm{Cu}$ (II) centre in this complex from component I to other unknown $\mathrm{Cu}$ (II) centre(s) (Fig. 6c) at high $\mathrm{pH}$; (iii) the redox activities of the two $\mathrm{Cu}$ complexes with a His1 $\mathrm{N}$-terminus are higher than all others and notably, the one with peptide $\mathrm{A} \beta 16-\mathrm{D} 1 \mathrm{H} / \mathrm{H} 14 \mathrm{~A}$ has the highest activity consistently at all pH values (Table 6). This high redox activity is attributed to a combined redox advantage of the $\mathrm{Cu}$ centres in both oxidation states and this is further analysed and discussed below.

\section{Determinants that regulate the redox activity of $\mathrm{Cu}-\mathrm{A} \beta$ peptides}

In order to be an efficient redox catalytic centre for a particular process of oxidation and reduction, the formal reduction

\begin{tabular}{|c|c|c|c|c|c|c|c|c|c|c|c|c|}
\hline \multirow[b]{2}{*}{$\mathrm{A} \beta 16$ peptide } & \multicolumn{3}{|c|}{$\begin{array}{l}\text { Catalytic rate as molar } \\
\text { velocity }\left(\mathrm{min}^{-1}\right) \text { at } \mathrm{pH}\end{array}$} & \multicolumn{3}{|c|}{$\begin{array}{l}\text { Relative to that with } \\
\mathrm{Cu}-\mathrm{D} 1 \mathrm{H} \text { as catalyst at } \mathrm{pH}\end{array}$} & \multicolumn{3}{|c|}{$\begin{array}{l}E_{\text {calc }}^{0^{\prime}}(\mathrm{mV} v s . \text { SHE }) \\
\text { at } \mathrm{pH}^{b}\end{array}$} & \multicolumn{3}{|c|}{$\begin{array}{l}E^{0 \prime}(\mathrm{mV} v s . \mathrm{SHE}) \\
\text { reported at } \mathrm{pH}^{c}\end{array}$} \\
\hline & 6.6 & 7.4 & 8.7 & 6.6 & 7.4 & 8.7 & 6.2 & 7.4 & 9.4 & $\sim 6.5$ & 7.4 & $\sim 8.5$ \\
\hline D1A & 0.09 & 0.08 & 0.17 & 0.13 & 0.10 & 0.06 & +277 & +242 & +40.9 & & & \\
\hline A2P & 0.32 & 0.66 & 1.12 & 0.46 & 0.84 & 0.42 & +247 & +206 & +70.4 & & & \\
\hline $\mathrm{D} 1 \mathrm{H}$ & 0.69 & 0.78 & 2.70 & 1.00 & 1.00 & 1.00 & +183 & +118 & +46.8 & & & \\
\hline $\mathrm{D} 1 \mathrm{H} / \mathrm{H} 14 \mathrm{~A}$ & 0.79 & 0.90 & 3.29 & 1.16 & 1.15 & 1.22 & +194 & +118 & +64.5 & & & \\
\hline Ac-A $\beta 16$ & & & & & & & & +277 & & & $+283^{5}$ & $-130^{5}$ \\
\hline
\end{tabular}

Table 6 Aerobic oxidation rate of ascorbate catalyzed by various $\mathrm{Cu}-\mathrm{A} \beta 16$ complexes and calculated thermodynamic reduction potentials ${ }^{a}$

${ }^{a}$ Conditions: $[\mathrm{Asc}]_{\mathrm{tot}}=50 \mu \mathrm{M} ;[\mathrm{Cu}-\text { peptide }]_{\mathrm{tot}}=1-20 \mu \mathrm{M}$ with a one-fold excess apo-peptide; buffers (50 mM) of Mops (pH 6.6 and 7.4) and Ches (pH 8.7). The background oxidation rate without the added $\mathrm{Cu}$ has been removed, see the Experimental section for details. ${ }^{b} \mathrm{Calculated}$ from eqn (8) using $E^{0}=+153 \mathrm{mV}$ for the redox couple $\mathrm{Cu}^{2+} / \mathrm{Cu}^{+}$(note: the $\mathrm{Cu}(\mathrm{I}) K_{\mathrm{D}}$ values at $\mathrm{pH} 6.6$ and 8.7 were not determined and thus the calculations used data at pH 6.2 and 9.4 instead). ${ }^{c}$ Determined by cyclic voltammetry, except a recent theoretical calculation predicted $+280 \mathrm{mV}$ for component $\mathrm{I}$ and -370 to $-810 \mathrm{mV}$ for component $\mathrm{II}^{43}$ 
potential of the copper centre must be lower than that of the oxidant but higher than that of the reductant. At $\mathrm{pH} 7.4$, the formal reduction potentials of ascorbate and dioxygen are $\sim+50 \mathrm{mV}^{56}$ and $\sim+300 \mathrm{mV}^{57}$ (vs. SHE), respectively.

The formal reduction potentials of the $\mathrm{Cu}-\mathrm{A} \beta$ complexes may be estimated via the Nernst relationship of eqn (8) from the respective $\mathrm{Cu}(\mathrm{I})$ and $\mathrm{Cu}(\mathrm{II})$ affinities of each $\mathrm{A} \beta 16$ peptide (Table 6). The reduction potentials are generally more negative for component II than for component I and decrease with increased $\mathrm{pH}$. This is consistent with the more dramatic stabilization effect for $\mathrm{Cu}$ (II) coordination at higher $\mathrm{pH}$, especially with the dominant coordination effect of the deprotonated amide nitrogen to the $\mathrm{Cu}(\mathrm{II})$ centre in component II. ${ }^{5,43}$ The calculated reduction potentials in this work from the respective dissociation constants generally match those determined experimentally by cyclic voltammetry or predicted from theoretical calculations (Table 6). However, it must be noted that the dissociation constants of the $\mathrm{Cu}-\mathrm{A} \beta$ complexes are quite large (indicating relatively weak binding). In addition, the estimated values vary considerably with experimental conditions, as do the reduction potentials determined by cyclic voltammetry (Table 6). The redox processes are frequently not well-defined due to the different coordination environments for $\mathrm{Cu}(\mathrm{I})$ and $\mathrm{Cu}(\mathrm{II})$. Consequently, it is difficult to define the reduction potentials consistently and accurately as can be seen from the data in Table 6. Nevertheless, the statistical data seen there at $\mathrm{pH} 7.4$ suggest that the reduction potentials of most $\mathrm{Cu}-\mathrm{A} \beta$ complexes studied in this work fall within the potential window for catalytic oxidation of ascorbate by dioxygen (Table 6) and therefore should have no significant thermodynamic impact on their efficiency as catalysts for the aerial oxidation of ascorbate. In fact, there is no clear correlation between the calculated reduction potentials and the observed catalytic rates at the three $\mathrm{pH}$ values tested (Table 6).

It is apparent that the difference in the redox activity of the $\mathrm{Cu}$ centre in each $\mathrm{A} \beta 16$ peptide must be attributed primarily to differences in reaction kinetics that are closely related to the binding modes for both $\mathrm{Cu}$ (I) and $\mathrm{Cu}$ (II). As an efficient catalytic centre, the metal ion must be able to shuttle between different oxidation states with minimal reorganization energy, ${ }^{44}$ but this condition is often not met for $\mathrm{Cu}$ that prefers different ligands and binding modes for its two biologically accessible oxidation states. Blue copper proteins such as plastocyanin and azurin that accommodate robust redox active $\mathrm{Cu}$ centres feature conformational rigidity in the protein structures that impose an 'entatic state' to the $\mathrm{Cu}$ centre for efficient electron transfer. ${ }^{58}$

Such 'entatic states' for A $\beta$ peptides, however, are problematic, given their flexibility and unstructured nature. The coordination spheres for $\mathrm{A} \beta$ peptides are decided primarily by the coordination preferences of each oxidation state of the $\mathrm{Cu}$ centre, as demonstrated above and in previous studies. ${ }^{3,8}$ Consequently, the $\mathrm{Cu}$ centres in $\mathrm{A} \beta$ peptides are generally not efficient redox catalysts since only a very small fraction of $\mathrm{Cu}$ centres in equilibrium are pre-organized for electron transfer ${ }^{44}$ and the catalytic activity of 'free' $\mathrm{Cu}$ is inhibited upon binding to $\mathrm{A} \beta$ peptides. ${ }^{8,55,59}$

At physiological $\mathrm{pH}, \mathrm{A} \beta 16$ binds one equiv. of $\mathrm{Cu}(\mathrm{I})$ or $\mathrm{Cu}(\mathrm{II})$ with sub-nanomolar affinities (Fig. 1). Component I in the $\mathrm{Cu}$ (II) system is more reactive in the catalytic oxidation of Asc than component II for several reasons: (i) component I shares two His ligands with each of the three possible $\mathrm{Cu}(\mathrm{I})$ sites while component II contains only one His ligand; (ii) the main $\mathrm{Cu}$ (II) ligands for component I are flexible amino acid sidechains while the dominant $\mathrm{Cu}$ (II) ligands for component II are derived from the peptide backbone with rigid fused chelate rings; (iii) a $\mathrm{Cu}-\mathrm{N}^{-}$bond arising from coordination to a negatively charged amide $\mathrm{N}^{-}$is highly covalent and any reactions involving such a chemical bond are usually slow. ${ }^{6,21,33,43}$ Consequently, component I is more reactive than component II, not only in redox catalysis but also in ligand substitution. ${ }^{5,6}$ These conclusions are consolidated by the observed reactivity orders for related peptides in ligand substitution ${ }^{6,21,33}$ and redox turnover (Table 6, eqn (10)). ${ }^{5}$ In particular, substitution of Asp1 with His1 not only locks the $\mathrm{Cu}(\mathrm{II})$ binding mode to the IA component within the pH range 6-9 (Fig. 4a(i) and 6b), but introduces a new $\mathrm{Cu}(\mathrm{I})$ ligand in the $\mathrm{N}$-terminus to be shared with the $\mathrm{Cu}$ (II) binding site. This leads to a considerable increase in the redox reactivity of the $\mathrm{Cu}$ centre. Interestingly, removal of the extra non-N-terminal ligand His14 from A $316-\mathrm{D} 1 \mathrm{H}$ leads to a further increase in redox activity (Table 6), presumably attributable to the increased similarity between the binding sites for both $\mathrm{Cu}(\mathrm{I})$ and $\mathrm{Cu}(\mathrm{II})$ in the $\mathrm{A} \beta 16$ D1H/H14A peptide.

\section{Summary and concluding remarks}

Monomeric A $\beta$ peptides are flexible and unstructured. Both metal binding ligands and binding modes change dynamically with the $\mathrm{Cu}$ oxidation state and with reaction conditions. A range of chemical and spectroscopic studies were carried out on copper complexes of several A $\beta 16$ peptides in which the two key residues for $\mathrm{Cu}(\mathrm{II})$ binding in the $\mathrm{N}$-terminal region were varied. Key conclusions are as follows:

(i) At lower $\mathrm{pH}$, the $\mathrm{A} \beta 16$ peptide binds $\mathrm{Cu}(\mathrm{II})$ predominantly as component IA in equilibrium with less stable component IB; at higher $\mathrm{pH}$, these are converted to component II with transition $\mathrm{p} K_{\mathrm{a}} \sim 7.8$ (Fig. 1b and 4b);

(ii) Component I sites involve flexible amino acid sidechains common to the $\mathrm{Cu}(\mathrm{I})$ binding ligands, but the metal sites for component II are dictated by a deprotonated backbone amide nitrogen that cannot act as a $\mathrm{Cu}(\mathrm{I})$ ligand and is slow to dissociate. ${ }^{5,6,43}$ Consequently, component $\mathrm{I}$ is more reactive than component II in both metal substitution and redox catalysis.

(iii) Substitution of Asp1 with His provides an extra imidazole ligand for $\mathrm{Cu}(\mathrm{I})$ and also allows the $\mathrm{N}$-terminal His1 to be part of a stable six-membered chelate ring for $\mathrm{Cu}(\mathrm{II})$ coordination. Consequently, the $\mathrm{Cu}(\mathrm{II})$ centre in $\mathrm{A} \beta 16-\mathrm{D} 1 \mathrm{H}$ is locked into component IA with a dramatic increase in its redox activity.

(iv) Replacement of Ala2 with Pro suppresses component II relative to component I and increases the reactivity of the bound copper.

(v) Substitution of Asp1 with Ala restricts component I to the less stable IB form that is readily converted to component II at physiological $\mathrm{pH}$ with decreased catalytic reactivity. 
This study provides insights into determinants that regulate the reactivity of copper toward $\mathrm{A} \beta$ peptides and may guide development towards a better understanding of the factors contributing to oxidative stress present within Alzheimer's disease.

\section{Abbreviations}

$\begin{array}{ll}\text { Asc } & \text { Ascorbate } \\ \text { Bca } & \text { Bicinchoninic anion } \\ \text { Bcs } & \text { Bathocupröine disulfonate } \\ \text { Ches } & N \text {-Cyclohexyl-2-aminoethanesulfonic acid } \\ \text { DP2 } & \text { Dansyl peptide } 2\left(\mathrm{DAE}\left(\mathrm{K}^{\mathrm{DNS}}\right) \mathrm{RHDH}\right) \\ \text { DP3 } & \text { Dansyl peptide } 3\left(\mathrm{HP}\left(\mathrm{K}^{\mathrm{DNS}}\right) \mathrm{DHDH}\right) \\ \text { DP4 } & \text { Dansyl peptide } 4\left(\mathrm{H}\left(\mathrm{K}^{\mathrm{DNS}}\right) \mathrm{HH}\right) \\ \text { eqn } & \text { Equation } \\ \text { equiv. } & \text { Equivalent } \\ \text { ESI-MS } & \text { Electrospray ionization mass spectrometry } \\ \text { Fs } & \text { Ferene S } \\ \text { Fz } & \text { Ferrozine } \\ \text { Hepes } & \text { 4-(2-Hydroxyethyl)-1-piperazineethanesulfonic acid } \\ \text { His } & \text { Histidine } \\ \text { Mes } & \text { 2-(N-Morpholino)ethanesulfonic acid } \\ \text { Mops } & 3 \text { - }(N \text {-Morpholino)propanesulfonic acid }\end{array}$

\section{Acknowledgements}

This work was supported by funding from the Australian Research Council Grant DP130100728. We thank Prof. Ashley Bush for comments and discussions and Mrs Sioe See Volaric for providing technical support for recording EPR spectra.

\section{References}

1 A. I. Bush, The metallobiology of Alzheimer's disease, Trends Neurosci., 2003, 26, 207-214.

2 K. P. Kepp, Bioinorganic Chemistry of Alzheimer's Disease, Chem. Rev., 2012, 112, 5193-5239.

3 C. Hureau, Coordination of redox active metal ions to the amyloid precursor protein and to amyloid- $\beta$ peptides involved in Alzheimer disease. Part 1: an overview, Coord. Chem. Rev., 2012, 256, 2164-2174.

4 C. Hureau and P. Dorlet, Coordination of redox active metal ions to the amyloid precursor protein and to amyloid- $\beta$ peptides involved in Alzheimer disease. Part 2: dependence of $\mathrm{Cu}(\mathrm{II})$ binding sites with $\mathrm{A} \beta$ sequences, Coord. Chem. Rev., 2012, 256, 2175-2187.

5 L. G. Trujano-Ortiz, F. J. González and L. Quintanar, Redox Cycling of Copper-Amyloid $\beta$ 1-16 Peptide Complexes Is Highly Dependent on the Coordination Mode, Inorg. Chem., 2015, 54, 4-6.

6 T. Branch, P. Girvan, M. Barahona and L. Ying, Introduction of a Fluorescent Probe to Amyloid- $\beta$ to Reveal Kinetic Insights into Its Interactions with Copper(II), Angew. Chem., Int. Ed., 2015, 54, 1227-1230.
7 C. Hureau, V. Balland, Y. Coppel, P. L. Solari, E. Fonda and P. Faller, Importance of dynamical processes in the coordination chemistry and redox conversion of copper amyloid-beta complexes, J. Biol. Inorg. Chem., 2009, 14, 995-1000.

8 T. R. Young, A. Kirchner, A. G. Wedd and Z. Xiao, An Integrated Study of the Affinities of the A $\beta 16$ Peptide for $\mathrm{Cu}(\mathrm{I})$ and $\mathrm{Cu}(\mathrm{II})$ : Implications for the Catalytic Production of Reactive Oxygen Species, Metallomics, 2014, 6, 505-517.

9 C. Hureau, Y. Coppel, P. Dorlet, P. L. Solari, S. Sayen, E. Guillon, L. Sabater and P. Faller, Deprotonation of the Asp1-Ala2 peptide bond induces modification of the dynamic copper(II) environment in the amyloid-beta peptide near physiological pH, Angew. Chem., Int. Ed., 2009, 48, 9522-9525.

10 S. C. Drew, C. J. Noble, C. L. Masters, G. R. Hanson and K. J. Barnham, Pleomorphic copper coordination by Alzheimer's disease amyloid-beta peptide, J. Am. Chem. Soc., 2009, 131, 1195-1207.

11 C. A. Damante, K. Osz, Z. Nagy, G. Pappalardo, G. Grasso, G. Impellizzeri, E. Rizzarelli and I. Sovago, The metal loading ability of beta-amyloid N-terminus: a combined potentiometric and spectroscopic study of copper(II) complexes with betaamyloid(1-16), its short or mutated peptide fragments, and its polyethylene glycol (PEG)-ylated analogue, Inorg. Chem., 2008, 47, 9669-9683.

12 P. Dorlet, S. Gambarelli, P. Faller and C. Hureau, Pulse EPR Spectroscopy Reveals the Coordination Sphere of Copper(II) Ions in the 1-16 Amyloid- $\beta$ Peptide: A Key Role of the First Two N-Terminus Residues, Angew. Chem., Int. Ed., 2009, 48, 9273-9276.

13 S. C. Drew, C. L. Masters and K. J. Barnham, Alanine-2 carbonyl is an oxygen ligand in $\mathrm{Cu}^{2+}$ coordination of Alzheimer's disease amyloid-beta peptide - relevance to N-terminally truncated forms, J. Am. Chem. Soc., 2009, 131, 8760-8761.

14 C. L. Masters, G. Multhaup, G. Simms, J. Pottgiesser, R. N. Martins and K. Beyreuther, Neuronal origin of a cerebral amyloid: neurofibrillary tangles of Alzheimer's disease contain the same protein as the amyloid of plaque cores and blood vessels, EMBO J., 1985, 4, 2757-2763.

15 C. L. Masters, G. Simms, N. A. Weinman, G. Multhaup, B. L. McDonald and K. Beyreuther, Amyloid plaque core protein in Alzheimer disease and Down syndrome, Proc. Natl. Acad. Sci. U. S. A., 1985, 82, 4245-4249.

16 J. W. Karr, H. Akintoye, L. J. Kaupp and V. A. Szalai, $\mathrm{N}$-Terminal deletions modify the $\mathrm{Cu}^{2+}$ binding site in amyloidbeta, Biochemistry, 2005, 44, 5478-5487.

17 J. W. Karr and V. A. Szalai, Role of aspartate- 1 in $\mathrm{Cu}$ (II) binding to the amyloid-beta peptide of Alzheimer's disease, J. Am. Chem. Soc., 2007, 129, 3796-3797.

18 C. Ghosh and S. G. Dey, Ligand-field and ligand-binding analysis of the active site of copper-bound Abeta associated with Alzheimer's disease, Inorg. Chem., 2013, 52, 1318-1327.

19 B. Alies, H. Eury, C. Bijani, L. Rechignat, P. Faller and C. Hureau, pH-Dependent $\mathrm{Cu}(\mathrm{II})$ coordination to amyloidbeta peptide: impact of sequence alterations, including the H6R and D7N familial mutations, Inorg. Chem., 2011, 50, 11192-11201. 
20 C. Harford and B. Sarkar, Amino Terminal Cu(II)- and Ni(II)Binding Motif of Proteins and Peptides: Metal Binding, DNA Cleavage, and Other Properties, Acc. Chem. Res., 1997, 30, 123-130.

21 T. R. Young, C. J. K. Wijekoon, B. Spyrou, P. S. Donnelly, A. G. Wedd and Z. Xiao, A Set of Robust Fluorescent Peptide Probes for Quantification of $\mathrm{Cu}$ (II) Binding Affinities in the Micromolar to Femtomolar Range, Metallomics, 2015, 7, 567-578.

22 M. Mital, N. E. Wezynfeld, T. Fraczyk, M. Z. Wiloch, U. E. Wawrzyniak, A. Bonna, C. Tumpach, K. J. Barnham, C. L. Haigh, W. Bal and S. C. Drew, A Functional Role for A $\beta$ in Metal Homeostasis? N-Truncation and High-Affinity Copper Binding, Angew. Chem., Int. Ed., 2015, 54, 10460-10464.

23 N. E. Wezynfeld, E. Stefaniak, K. Stachucy, A. Drozd, D. Płonka, S. C. Drew, A. Krężel and W. Bal, Resistance of $\mathrm{Cu}(\mathrm{A} \beta 4-16)$ to Copper Capture by Metallothionein-3 Supports a Function for the A $\beta 4-42$ Peptide as a Synaptic CuII Scavenger, Angew. Chem., Int. Ed., 2016, 55, 8235-8238.

24 K. Y. Djoko, Z. Xiao, D. L. Huffman and A. G. Wedd, Conserved Mechanism of Copper Binding and Transfer. A Comparison of the Copper-Resistance Proteins PcoC from Escherichia coli and CopC from Pseudomonas syringae, Inorg. Chem., 2007, 46, 4560-4568.

25 W. M. Kok, J. M. Cottam, G. D. Ciccotosto, L. A. Miles, J. A. Karas, D. B. Scanlon, B. R. Roberts, M. W. Parker, R. Cappai, K. J. Barnham and C. A. Hutton, Synthetic dityrosine-linked [small beta]-amyloid dimers form stable, soluble, neurotoxic oligomers, Chem. Sci., 2013, 4, 4449-4454.

26 Z. Xiao, L. Gottschlich, R. van der Meulen, S. R. Udagedara and A. G. Wedd, Evaluation of quantitative probes for weaker $\mathrm{Cu}(\mathrm{I})$ binding sites completes a set of four capable of detecting $\mathrm{Cu}(\mathrm{I})$ affinities from nanomolar to attomolar, Metallomics, 2013, 5, 501-513.

27 Z. Xiao, J. Brose, S. Schimo, S. M. Ackland, S. La Fontaine and A. G. Wedd, Unification of the copper(I) binding affinities of the metallo-chaperones Atx1, Atox1 and related proteins: detection probes and affinity standards, J. Biol. Chem., 2011, 286, 11047-11055.

28 M. I. Karayannis, D. N. Samios and C. H. P. Gousetis, A study of the molar absorptivity of ascorbic acid at different wavelengths and pH values, Anal. Chim. Acta, 1977, 93, 275-279.

29 G. Milazzo and S. Caroli, Tables of Standard Electrode Potentials, Wiley, New York, 1978.

30 C. Reinhard, S. S. Hebert and B. De Strooper, The amyloidbeta precursor protein: integrating structure with biological function, EMBO J., 2005, 24, 3996-4006.

31 A. I. Bush, C. L. Masters and R. E. Tanzi, Copper, beta-amyloid, and Alzheimer's disease: tapping a sensitive connection, Proc. Natl. Acad. Sci. U. S. A., 2003, 100, 11193-11194.

32 M. W. Beck, S. B. Oh, R. A. Kerr, H. J. Lee, S. H. Kim, S. Kim, M. Jang, B. T. Ruotolo, J.-Y. Lee and M. H. Lim, A rationally designed small molecule for identifying an in vivo link between metal-amyloid- $\beta$ complexes and the pathogenesis of Alzheimer's disease, Chem. Sci., 2015, 6, 1879-1886.

33 C. J. K. Wijekoon, T. R. Young, A. G. Wedd and Z. Xiao, The CopC Protein from Pseudomonas Fluorescens SBW25
Features A Conserved Novel High Affinity Cu(II) Binding Site, Inorg. Chem., 2015, 54, 2950-2959.

34 L. Zhang, M. Koay, M. J. Maher, Z. Xiao and A. G. Wedd, Intermolecular transfer of copper ions from the CopC protein of Pseudomonas syringae. Crystal structures of fully loaded $\mathrm{Cu}(\mathrm{I}) \mathrm{Cu}(\mathrm{II})$ forms, J. Am. Chem. Soc., 2006, 128, 5834-5850.

35 T. J. Lawton, G. E. Kenney, J. D. Hurley and A. C. Rosenzweig, The CopC Family: Structural and Bioinformatic Insights into a Diverse Group of Periplasmic Copper Binding Proteins, Biochemistry, 2016, 55, 2278-2290.

36 C. Kállay, K. Várnagy, G. Micera, D. Sanna and I. Sóvágó, Copper(II) complexes of oligopeptides containing aspartyl and glutamyl residues. Potentiometric and spectroscopic studies, J. Inorg. Biochem., 2005, 99, 1514-1525.

37 I. Sovago and K. Osz, Metal ion selectivity of oligopeptides, Dalton Trans., 2006, 3841-3854, DOI: 10.1039/B607515K.

38 X. Huang, M. P. Cuajungco, C. S. Atwood, M. A. Hartshorn, J. D. A. Tyndall, G. R. Hanson, K. C. Stokes, M. Leopold, G. Multhaup, L. E. Goldstein, R. C. Scarpa, A. J. Saunders, J. Lim, R. D. Moir, C. Glabe, E. F. Bowden, C. L. Masters, D. P. Fairlie, R. E. Tanzi and A. I. Bush, Cu(II) potentiation of Alzheimer $A \beta$ neurotoxicity: correlation with cell-free hydrogen peroxide production and metal reduction, J. Biol. Chem., 1999, 274, 37111-37116.

39 R. A. Himes, G. Y. Park, G. S. Siluvai, N. J. Blackburn and K. D. Karlin, Structural Studies of Copper(I) Complexes of Amyloid- $\beta$ Peptide Fragments: Formation of Two-Coordinate Bis(histidine) Complexes, Angew. Chem., Int. Ed., 2008, 47, 9084-9087.

40 J. Shearer and V. A. Szalai, The Amyloid- $\beta$ Peptide of Alzheimer's Disease Binds CuI in a Linear Bis-His Coordination Environment: Insight into a Possible Neuroprotective Mechanism for the Amyloid- $\beta$ Peptide, J. Am. Chem. Soc., 2008, 130, 17826-17835.

41 S. Furlan, C. Hureau, P. Faller and G. La Penna, Modeling the $\mathrm{Cu}+$ binding in the 1-16 region of the amyloid-beta peptide involved in Alzheimer's disease, J. Phys. Chem. B, 2010, 114, 15119-15133.

42 L. Guilloreau, S. Combalbert, A. Sournia-Saquet, H. Mazarguil and P. Faller, Redox chemistry of copper-amyloid-beta: the generation of hydroxyl radical in the presence of ascorbate is linked to redox-potentials and aggregation state, ChemBioChem, 2007, 8, 1317-1325.

43 J. Alí-Torres, A. Mirats, J.-D. Maréchal, L. Rodríguez-Santiago and M. Sodupe, 3D Structures and Redox Potentials of $\mathrm{Cu}^{2+}-$ $\mathrm{A} \beta(1-16)$ Complexes at Different $\mathrm{pH}$ : A Computational Study, J. Phys. Chem. B, 2014, 118, 4840-4850.

44 V. Balland, C. Hureau and J.-M. Savéant, Electrochemical and homogeneous electron transfers to the Alzheimer amyloid- $\beta$ copper complex follow a preorganization mechanism, Proc. Natl. Acad. Sci. U. S. A., 2010, 107, 17113-17118.

45 D. Jiang, L. Men, J. Wang, Y. Zhang, S. Chickenyen, Y. Wang and F. Zhou, Redox reactions of copper complexes formed with different $\beta$-amyloid peptides and their neuropathalogical relevance, Biochemistry, 2007, 46, 9270-9282. 
46 X. Zhu, B. Su, X. Wang, M. A. Smith and G. Perry, Causes of oxidative stress in Alzheimer disease, Cell. Mol. Life Sci., 2007, 64, 2202-2210.

47 C. Opazo, X. Huang, R. A. Cherny, R. D. Moir, A. E. Roher, A. R. White, R. Cappai, C. L. Masters, R. E. Tanzi, N. C. Inestrosa and A. I. Bush, Metalloenzyme-like activity of Alzheimer's disease beta-amyloid. Cu-dependent catalytic conversion of dopamine, cholesterol, and biological reducing agents to neurotoxic $\mathrm{H}_{2} \mathrm{O}_{2}$, J. Biol. Chem., 2002, 277, 40302-40308.

48 X. Huang, C. S. Atwood, M. A. Hartshorn, G. Multhaup, L. E. Goldstein, R. C. Scarpa, M. P. Cuajungco, D. N. Gray, J. Lim, R. D. Moir, R. E. Tanzi and A. I. Bush, The A beta peptide of Alzheimer's disease directly produces hydrogen peroxide through metal ion reduction, Biochemistry, 1999, 38, 7609-7616.

49 C. Cheignon, P. Faller, D. Testemale, C. Hureau and F. Collin, Metal-catalyzed oxidation of $\mathrm{A}$ [small beta] and the resulting reorganization of $\mathrm{Cu}$ binding sites promote ROS production, Metallomics, 2016, 8, 1081-1089.

50 C. S. Atwood, G. Perry, H. Zeng, Y. Kato, W. D. Jones, K.-Q. Ling, X. Huang, R. D. Moir, D. Wang, L. M. Sayre, M. A. Smith, S. G. Chen and A. I. Bush, Copper Mediates Dityrosine Cross-Linking of Alzheimer's Amyloid- $\beta$, Biochemistry, 2004, 43, 560-568.

51 R. A. Grünewald, Ascorbic acid in the brain, Brain Res. Rev., 1993, 18, 123-133.
$52 \mathrm{M}$. E. Rice, Ascorbate regulation and its neuroprotective role in the brain, Trends Neurosci., 2000, 23, 209-216.

53 G. Eskici and P. H. Axelsen, Copper and Oxidative Stress in the Pathogenesis of Alzheimer's Disease, Biochemistry, 2012, 51, 6289-6311.

54 K. Reybier, S. Ayala, B. Alies, J. V. Rodrigues, S. Bustos Rodriguez, G. La Penna, F. Collin, C. M. Gomes, C. Hureau and $\mathrm{P}$. Faller, Free Superoxide is an Intermediate in the Production of $\mathrm{H}_{2} \mathrm{O}_{2}$ by Copper(I)-A $\beta$ Peptide and $\mathrm{O}_{2}$, Angew. Chem., Int. Ed., 2016, 55, 1085-1089.

55 B. Alies, I. Sasaki, O. Proux, S. Sayen, E. Guillon, P. Faller and C. Hureau, $\mathrm{Zn}$ impacts $\mathrm{Cu}$ coordination to amyloid[small beta], the Alzheimer's peptide, but not the ROS production and the associated cell toxicity, Chem. Commun., 2013, 49, 1214-1216.

56 B. E. Conway, Electrochemical Data, Greenwood Press, New York, 1969.

57 D. L. Nelson and M. M. Cox, Lehninger Principles of Biochemistry, W. H. Freeman, New York, 2004.

58 R. J. P. Williams, Metallo-enzyme catalysis: the entatic state, J. Mol. Catal., 1985, 30, 1-26.

59 S. L. Leong, T. R. Young, K. J. Barnham, A. G. Wedd, M. G. Hinds, Z. Xiao and R. Cappai, Quantification of Copper Binding to Amyloid Precursor Protein Domain 2 and its Caenorhabditis Elegans Ortholog. Implications for Biological Function, Metallomics, 2014, 6, 105-116. 